\title{
Voltage- and Transmitter-gated Currents of All-Amacrine Cells in a Slice Preparation of the Rat Retina
}

\author{
Reimund Boos, Horst Schneider, and Heinz Wässle \\ Max-Planck-Institut für Hirnforschung, W-6000 Frankfurt 71, Germany
}

\begin{abstract}
All-amacrine cells are crucial interneurons in the rod pathway of the mammalian retina. They receive input synapses from rod bipolar cells and make electrical output synapses into the ON-pathway and glycinergic chemical synapses into the OFF-pathway. Whole-cell currents from more than $\mathbf{5 0}$ voltage-clamped All-amacrine cells were recorded in a slice preparation of the rat retina. The recorded cells were identified by intracellular staining with Lucifer yellow. Spike-like potentials could be elicited upon depolarization by current injection. A voltage-activated, fast, TTX-sensitive, inward $\mathrm{Na}^{+}$current was identified. A prominent outward $\mathrm{K}^{+}$current could be suppressed by tetraethylammonium. GABA as well as glycine activated $\mathrm{Cl}^{-}$channels, which could be blocked by bicuculline and strychnine, respectively. Four agonists of excitatory amino acid receptors-kainate (KA), AMPA, 2-amino-4-phosphonobutyrate (APB), and NMDA-were tested. Inward currents at holding potentials of $V_{H}=-70$ $\mathrm{mV}$ were found by application of KA and AMPA but not by application of APB and NMDA. These currents could be blocked by 6-cyano-7-nitroquinoxaline-2,3-dione (CNQX). ACh did not evoke any current responses.
\end{abstract}

[Key words: mammalian retina, amacrine cells, retinal sllce, GABA, glycine, glutamate, neurobiotin coupling]

In the photopic pathway of the mammalian retina, cones feed into cone bipolar cells, which comprise two basic physiological types: ON-bipolar cells that are depolarized and OFF-bipolar cells that are hyperpolarized by a light stimulus. Cone bipolar cells synapse onto ganglion and amacrine cells. In the scotopic pathway rods are connected to rod bipolar cells, but instead of these synapsing directly onto ganglion cells, a distinctive type of narrow-field amacrine cell, the so-called AII-amacrine cell, is interposed (Kolb and Famiglietti, 1974; Famiglietti and Kolb, 1975; Kolb, 1979; Sterling, 1983; Strettoi et al., 1992). AIIamacrines make conventional chemical synapses with OFFcone bipolar and OFF-ganglion cells and contact ON-cone bipolar cells via large gap junctions. In this way they could produce signals of opposite polarity in ON- and OFF-ganglion cells.

This wiring diagram is mainly based on ultrastructural observations in cats (Kolb and Famiglietti, 1974; Famiglietti and

\footnotetext{
Received Oct. 21, 1992; revised Jan. 8, 1993; accepted Jan. 20, 1993.

We thank F. Boij and U. Pieper for technical assistance and I. Odenthal for typing the manuscript. We are grateful to Dr. Ulrike Grünert for help in histology. We thank Dr. Andrew Ishida, Dr. Rowland Taylor, and Dr. Martin Wilson for helpful discussions.

Correspondence should be addressed to Heinz Wässle, Max-Planck-Institut für Hirnforschung, Deutschordenstrasse 46, W-6000 Frankfurt 71, Germany.

Copyright (C) 1993 Society for Neuroscience $0270-6474 / 93 / 132874-15 \$ 05.00 / 0$
}

Kolb, 1975; Sterling, 1983), rabbits (Dacheux and Raviola, 1986; Strettoi et al., 1990, 1992), and rats (Chun et al., 1993). However, AII-amacrine cells are constituents of all mammalian retinas looked at so far, and it is very likely that the rod pathway is essentially identical in all mammals (Daw et al., 1990; Vaney, 1990; Wässle and Boycott, 1991).

The morphology and topographic distribution of AII-amacrine cells have been elaborated in the cat (Vaney, 1985), rabbit (Mills and Massey, 1991; Vaney et al., 1991), and rat retina (Chun et al., 1993; Wässle et al., 1993). The AII-amacrine cells are small, distinctly bistratified cells, with so-called lobular appendages in sublamina $a$ of the inner plexiform layer (IPL) and bushy dendritic fields in sublamina $b$ (Perry and Walker, 1980). Their cell bodies are about $7-10 \mu \mathrm{m}$ in diameter; in the vertical view they protrude slightly into the IPL and give rise to one or several stout processes that descend into the IPL. In the cat and rabbit retina they comprise about $10 \%$ of all amacrines (Vaney, 1985; Vaney et al., 1991); in the rat retina their percentage is approximately 8-9\% (Wässle et al., 1993). The AlI-amacrine cells are probably the most numerous amacrine cell type in these retinas (Vaney, 1990).

AII-amacrine cells of the cat retina have been shown to accumulate ${ }^{3} \mathrm{H}$-glycine (Pourcho and Goebel, 1985) and to express glycine immunoreactivity (Pourcho and Goebel, 1987). Hence, they are very likely glycinergic interneurons.

Light responses of AII-amacrine cells are depolarizing in the cat and in the rabbit retina (Nelson, 1982; Dacheux and Raviola, 1986). In the rabbit retina they produce small action potentials, and little spike-like potentials were also observed in cat AIIamacrines. Light responses of rod bipolar cells have been reported to be hyperpolarizing in cat (Kolb and Nelson, 1983; Nelson and Kolb, 1983) and depolarizing in the rabbit (Dacheux and Raviola, 1986). However, recent evidence from the darkadapted in vivo cat retina (Müller et al., 1988) and from dissociated rod bipolar cells (Yamashita and Wässle, 1991b; Kaneko et al., 1992) suggests that rod bipolar cells are depolarizing bipolar cells. A single AII-amacrine cell receives synaptic input from as many as 30 rod bipolar cells (Sterling et al., 1988; Vaney et al., 1991).

Voltage- and transmitter-gated currents of rod bipolar cells have been studied from dissociated cells of the cat, mouse, and rat retinas (Kaneko et al., 1989, 1992; Karschin and Wässle, 1990; Yeh et al., 1990; Yamashita and Wässle, 1991a,b). This has been possible because the characteristic morphology of rod bipolar cells is not lost during the dissociation procedure and they can be recognized by immunocytochemical markers (Negishi et al., 1988; Greferath et al., 1990). Although we searched through many Petri dishes of dissociated retinal cells, we did 
not observe AII cells. Apparently they lose their processes during dissociation, and since they cannot be labeled by other meanssuch as ganglion cells by retrograde transport of fluorescent tracers-they could not be identified for electrophysiological recording.

In order to study the voltage- and transmitter-gated currents of AII-amacrine cells, a thin slice preparation for patch-clamp recordings from neurons of the mammalian retina was established (Werblin, 1978; Wu, 1987; Edwards et al., 1989). The electrodes contained Lucifer yellow (LY), which made identification of AII-amacrine cells possible. Whole-cell currents werc recorded in response to voltage steps and the currents were identified as $\mathrm{Na}^{+}$or $\mathrm{K}^{+}$currents. Transmitter-gated currents were studied by application of agonists and antagonists through a multibarrel puffer pipette. No precautions were taken to preserve light responses, which were recorded only occasionally in this slice preparation.

\section{Materials and Methods}

Preparation of slices. Adult albino rats were deeply anesthetized with halothane and decapitated. The eyes were quickly enucleated and transferred into a plastic Petri dish containing physiological saline (E1 of Table 1) at $0-4^{\circ} \mathrm{C}$. The eye was opened by an encircling cut and the retina was carefully dissected free. The retina was then cut into four pieces. One of these pieces was held with a pair of forceps and, by "rolling" the curved surface of a scalpel blade over the edge, thin slices of $100-200 \mu \mathrm{m}$ thickness were cut. We find that this procedure, with some practice, gives better slices than vibratomes. Approximately 10 slices were cut in this way and transferred into a recording chamber. The other three pieces of retina were transferred into a holding chamber containing physiological saline (solution E2 of Table 1) at room tcmperature, where they were continuously oxygenized with carbogen $(95 \%$ $\mathrm{O}_{2}, 5 \% \mathrm{CO}_{2}$ ). The retinas survived in good condition up to $8 \mathrm{hr}$ in the holding chamber.

Recording chamber and optical setup. The recording chamber was placed on the fixed stage of a microscope (Zeiss ACM). The microscope was equipped with a focusing system, which moved the objectives, epifluorescence illumination, and differential interference contrast (Nomarski) optics. A water-immersion objective with a working distance of $1.6 \mathrm{~mm}$ was used (Zeiss, $40 / 0.75 \mathrm{~W}$ ), the metal parts of which were coated with Epon to avoid corrosion and contact voltages. The recording chamber was made out of Perspex and was continuously perfused with extracellular solution. The volume in the chamber was $600 \mu \mathrm{l}$ and the perfusion rate was $2 \mathrm{ml} / \mathrm{min}$. The bottle containing extracellular solution was kept at room temperature $\left(18-22^{\circ} \mathrm{C}\right)$ and continuously bubbled with carbogen.

In the recording chamber the slices were held in place with a grid of parallel nylon threads (Konnerth et al., 1987; Edwards et al., 1989). The electrode was mounted on a Leitz micromanipulator and approached the slices at a shallow angle ( $15^{\circ}$ to the horizontal plane). Fine adjustment was possible with the aid of a piezoelectric manipulator (Physik Instrumente, Waldbronn, Germany). Patch pipettes were pulled from borosilicate glass (Clark, Redding, UK; outer diameter, $1.5 \mathrm{~mm}$; wall thickness, $0.3 \mathrm{~mm}$ ) on a horizontal electrode puller (DMZ-Universal Puller, Zeitz Instrumente, Augsburg, Germany). After heat polishing, their tip diameter was approximately $1 \mu \mathrm{m}$ and their resistance with standard intracellular solution was 8-13 M . All recordings were made with an EPC-7 patch-clamp amplifier (List, Darmstadt, Germany). The recording electrode was connected with $\mathrm{Ag} / \mathrm{AgCl}$ wire to the preamplifier; the reference electrode was an $\mathrm{Ag} / \mathrm{AgCl}$ pellet in the recording chamber. Liquid junction potentials of the patch pipette were measured as described by Fenwick et al. (1982). The holding potentials were corrected for junction potentials. Capacitative currents caused by the electrodes were canceled by the circuit of the EPC-7 amplifier. Additional capacitative currents appeared after breaking into the cells, reflecting the capacitance of the cells. The series resistances were estimated from the peak amplitudes of the capacitative currents. They were approximately $20 \mathrm{M} \Omega$. The capacitative currents could not be fitted by a single exponential, indicating the cells are not isopotential. Early attempts to cancel the series resistance by the circuit of the EPC-7 amplifier were not successful, since cells were lost easily due to the instabilities introduced
Table 1. Summary of the bath solutions (E1-E4) and of the electrode solutions $(\mathrm{I1}, \mathrm{I2})$ used in the present study

\begin{tabular}{|c|c|c|c|c|c|c|}
\hline & E1 & $\mathrm{E} 2$ & E3 & E4 & II & I2 \\
\hline $\mathrm{NaCl}$ & 137 & 110 & 110 & 137 & 10 & 10 \\
\hline $\mathrm{KCl}$ & 5 & 5 & 5 & 5 & 130 & \\
\hline $\mathrm{CaCl}_{2}$ & 2 & 2 & 2 & 2 & 1 & 1 \\
\hline $\mathrm{MgCl}_{2}$ & & & & & 2 & 1 \\
\hline $\mathrm{MgSO}_{4}$ & 1 & 1 & & & & \\
\hline $\mathrm{Na}_{2} \mathrm{HPO}_{4}$ & 1 & 1 & & & & \\
\hline $\mathrm{NaHCO}_{3}$ & & 25 & 25 & & & \\
\hline $\mathrm{CsCl}_{2}$ & & & & & & 120 \\
\hline $\mathrm{CoCl}_{2}$ & & & 3 & 2 & & \\
\hline Glucose & 15 & 15 & 15 & 15 & & \\
\hline HEPES & 10 & 10 & 10 & 10 & 10 & 10 \\
\hline TEA-Cl & & & & & & 15 \\
\hline ATP & & & & & 2 & 2 \\
\hline EGTA & & & & & 1.1 & 1.5 \\
\hline Glycine & & & & $0.5 \mu \mathrm{M}$ & & \\
\hline $\mathrm{pH}$ & 7.4 & 7.4 & 7.4 & 7.4 & 7.2 & 7.2 \\
\hline
\end{tabular}

All numbers are millimolar concentrations, with the exception of glycine, where the concentration is micromolar.

by the feedback circuitry. Hence, in later experiments the series resistance of the electrode was not compensated for. Series resistance was measured and steady state (DC) series resistance errors were accounted for numerically when quoting command voltages.

The voltage protocols were generated on an IBM-compatible personal computer and applied through an interface (Labmaster/TL-1, pCLAMP software 5.5, Axon Instruments). The data were low-pass filtered bctween 3 and $10 \mathrm{kHz}$ by a variable frequency filter (AP-255-5, A.P. Circuit Corp.). Depending upon the time resolution needed, the sampling interval could be varied from $24 \mu \mathrm{sec}$ to $40 \mathrm{msec}$.

Whole-cell recording. Both conventional (Hamill et al., 1981) and perforated-patch techniques (Horn and Marty, 1988) were used. In the conventional mode electrodes were filled with standard intracellular solution (solutions I1, I2 of Table 1). The seal resistance between the electrode and the cell was routinely greater than $10 \mathrm{G} \Omega$. Since Lucifer yellow (LY) was added to the electrode solution $(0.2 \mathrm{mg} / \mathrm{ml})$, rapid loading of the cell was achieved after rupturing the patch and establishing the whole-cell configuration. Within less than 1 min dendrites were well filled (Fig. 1).

In the perforated-patch method (Horn and Marty, 1988) the electrode was filled with the solution I1 (Table 1). Nystatin (Serva, Ileidelberg, Germany) was dissolved in dimethyl sulfoxide (Sigma, Deisenhofen, Germany) at a concentration of $100 \mathrm{mg} / \mathrm{ml}$ and added to the electrode solution at a final concentration of $300 \mu \mathrm{g} / \mathrm{ml}$. The electrode tip was positioned on the cell surface and a gigaohm seal was made by gentle suction. No suction was applied to the pipette after the initial seal formation. As described in detail by Horn and Marty (1988) and Yamashita and Wässle $(1991 \mathrm{a}, \mathrm{b})$, within 2 min after the seal formation, nystatin made the membrane of the cell-attached patch electrically permeable without rupture ("perforated patch"). No filling of the cells with LY was observed, indicating that the patch was not broken. At the end of the recordings, gentle suction ruptured the patch, LY diffused into the cells, and their morphology became apparent.

Drug application and solutions. The different extracellular and electrode solutions are listed in Table 1 and will be specified in Results. Drugs were dissolved in the bath solution and applied from six-barrelled pneumatic puffer pipettes. The tip diameter of each pipette was about $10 \mu \mathrm{m}$ and the pipettes were placed close $(20-25 \mu \mathrm{m})$ to the cell (Fig. 1). In control experiments all six barrels were filled with the same solution, for example, $2 \mu \mathrm{M}$ GABA, to make sure that each barrel was positioned correctly to allow the test solutions to engulf the recorded cells maximally. Differences of less than $20 \%$ were found in whole-cell currents when the different barrels were activated. Movements of the puffer pipette by $20-30 \mu \mathrm{m}$ did not significantly change the responses. Air pressure $(0.3-0.5$ bar) was applied under computer control. Without the pressure, bath solution continuously flowed into the pipettes by capillary attraction. This effect prevented the test solutions from leaking 

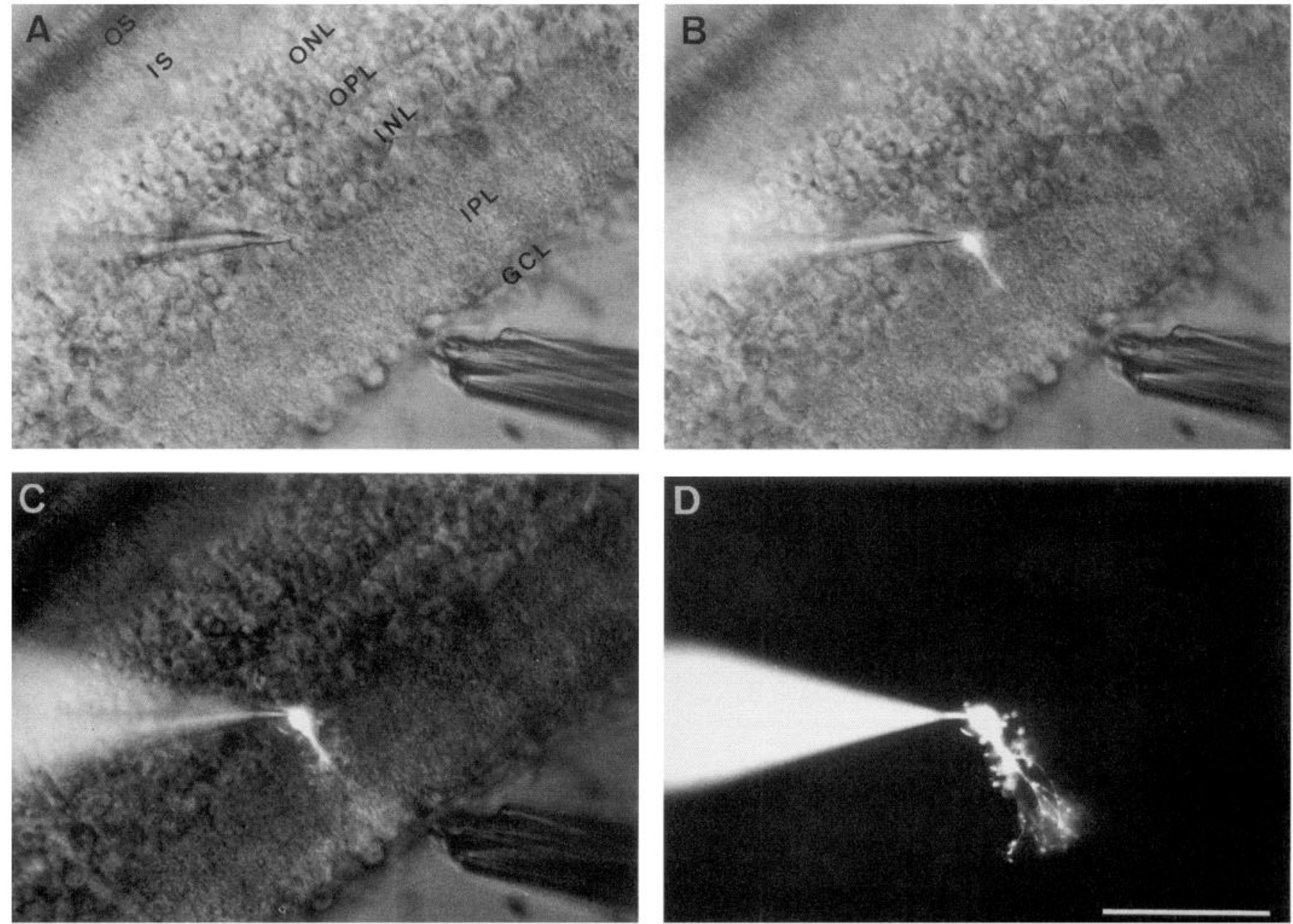

Figure 1. Slice preparation of a rat retina during patch-clamp recordings from an AII-amacrine cell. $A$, In this Nomarski micrograph the retinal layers are indicated $(O S$, rod outer segments; $I S$, rod inner segments; $O N L$, outer nuclear layer; $O P L$, outer plexiform layer; $I N L$, inner nuclear layer; $I P L$, inner plexiform layer; $G C L$, ganglion cell layer). The patch electrode, of which only the tip is in focus, approaches an AII-amacrine cell body from the left side. The puffer pipette can be seen in the lower right corner. B, Using translucent light and epifluorescence one can see the cell body of the AII-amacrine cell, whose membrane was ruptured by the patch electrode, filled with LY. $C$, With this focal plane the dendritic tree of the LY-filled AII-amacrine cell and its stratification in the IPL can be seen. $D$, Using only epifluorescence illumination the typical bistratified morphology of the AII-amacrine cell and the patch electrode become apparent. In the outer part of the IPL the AII has the so-called lobular appendages; in the inner part, a bushy dendritic tree. Scale bar, $50 \mu \mathrm{m}$.

out. The concentration of drugs (given in parentheses) refers to the concentrations in the barrel of the puffer pipette. The actual concentrations at the cell membranes are lower and not known. Glutamate (2 mм), kainate (KA; $0.2 \mathrm{~mm})$, GABA $(2 \mu \mathrm{M})$, glycine $(0.2 \mathrm{~mm})$, acetylcholine ( $1 \mathrm{~mm}$ ), taurine $(0.5 \mathrm{~mm})$, and tetrodotoxin (TTX; $1 \mu \mathrm{M})$ were obtained from Sigma (Deisenhofen, Germany). L-2-Aminophosphonobutyric acid (L-APB; $0.2 \mathrm{~mm}$ ), $N$-methyl-D-aspartate (NMDA; $1 \mathrm{~mm}$ ), and 6-cyanoquinoxaline-2,3-dione (CNQX; $20 \mu \mathrm{M}$ ) were obtained from Cambridge Research Biochemicals (Cambridge, UK). Muscimol (10 $\mu \mathrm{M})$ was purchased from Research Biochemical Incorporated (Natick, MA). AMPA (0.1 mM) was obtained from Tocris Neuramin (Bristol, UK). The following drugs were dissolved in extracellular solution and bath applied: strychnine ( $1 \mu \mathrm{M}$; Serva, Heidelberg, Germany), bicuculline (20 $\mu \mathrm{M}$; Cambridge Research Biochemicals, Cambridge, UK), tetraethylammonium (TEA; 10-25 mM; Merck, Darmstadt, Germany), and 4-aminopyridine (4-AP; 10 mm; Merck, Darmstadt, Germany). HEPES and nystatin were purchased from Serva (Heidelberg, Germany), Lucifer yellow, from Sigma (Deisenhofen, Germany); and all other chemicals, from Merck (Darmstadt, Germany).

The level of light adaptation of the retinal slice. The room lights were switched on during all experimental procedures. For dissection of the retina and during the slicing procedure the Petri dish was illuminated by the light beam of the dissection microscope (OMI, Zeiss, Oberkochen,
Germany). When approaching individual cells the translucent illumination of the microscope was switched on, and for identification of the Lucifer yellow-filled cells epifluorescent illumination was applied. Hence, the general status of the retinal slice is very likely light adapted.

Tracer coupling and immunostaining of AII-amacrine cells. In some experiments patch electrodes were filled with standard intracellular solution to which Lucifer yellow $(0.2 \mathrm{mg} / \mathrm{ml})$ and neurobiotin $(15 \mathrm{mg} / \mathrm{ml})$ (Vector, Burlingame, CA) were added (Horikawa and Armstrong, 1988). Neurobiotin has recently been reported to show tracer coupling of AIIamacrine cells (Vaney, 1991; Hampson et al., 1992). Within less than $1 \mathrm{~min}$ LY filled all the dendrites of the AII cell recorded in the wholecell mode; hence, rapid filling with neurobiotin can also be expected. After varying recording times, usually $10-20 \mathrm{~min}$, the slices were fixed for $40 \mathrm{~min}$ in $4 \%$ paraformaldehyde in $0.1 \mathrm{~m}$ phosphate-buffered saline (PBS), $\mathrm{pH}$ 7.4. They were washed three times for $10 \mathrm{~min}$ in PBS, incubated for $30 \mathrm{~min}$ in $0.5 \%$ Triton $\mathrm{X}-100$ in PBS, and then reacted with 1:100 extravidin (Sigma) in PBS for $2-3 \mathrm{hr}$. The slices were incubated for $10 \mathrm{~min}$ in $0.05 \%$ 3,3'-diaminobenzidine (Sigma) in PBS with $0.01 \%$ hydrogen peroxide. They were washed three times for $10 \mathrm{~min}$ in PBS and then coverslipped in $90 \%$ glycerine in phoshate buffer.

Details of the immunocytochemical staining of frozen sections of the rat retina with antibodies against parvalbumin are given elsewhere (Röhrenbeck et al., 1987, 1989; Wässle et al., 1993). 


\section{Results}

\section{Identification of AII-amacrine cells}

The layers of the retina and individual neurons can be recognized in the slices using Nomarski optics (Fig. 1A). Since AIIamacrine cells are the most numerous amacrine type and because their cell body protrudes into the IPL (Perry and Walker, 1980; Voigt and Wässle, 1987), with some experience one can select them for recording with a rather high success rate. However, every cell recorded was filled with LY to make sure that it was an AII-amacrine cell. The presence of the dye in the cell had no obvious effect on the currents recorded (Stewart, 1978; Eliasof et al., 1987; Werblin et al., 1988; Edwards et al., 1989). Altogether, 53 AII-amacrine cells were successfully recorded from and stained in the present study. Figure $1 B-D$ shows micrographs of an AII-amacrine cell with the patch electrode attached during the recordings in the slice chamber, and the typical bistratified AII morphology becomes apparent. The cell body protrudes slightly into the IPL and a stout single process leaves the cell body (Fig. 1D). In the outer third of the IPL the lobular appendages are found; in the inner third a densely branched dendritic plexus is stained. It was often difficult to remove the recording electrode from the cell body without pulling the cell apart. Therefore, most cells were photographed with the electrode attached to the cell body. Somctimes cell processes were damaged by the slicing and such cells are not included in the present analysis. Recordings from individual cells were usually stable for about half an hour.

\section{Coupling of AII-amacrine cells}

Electron microscopical reconstructions of AII-amacrine cells have demonstrated extensive gap junctions with ON-bipolar cells and with other AII-amacrine cells (Kolb and Famiglietti, 1974; Famiglietti and Kolb, 1975). More recently it has been shown that AII-amacrine cells of the rabbit retina show tracer coupling when injected with biocytin or neurobiotin (Vaney, 1991; Hampson et al., 1992). The extent of coupling could be modulated by dopamine; hence, it may depend on the level of light adaptation. In order to find out whether AII-amacrine cells in the slice preparation used for this study are coupled, patch electrodes were filled with LY and neurobiotin. The cells recorded from could be identified during the experiment by the LY filling, and afterward the slice was fixed and reacted for neurobiotin (Horikawa and Armstrong, 1988; Vaney, 1991). Figure 2, $A$ and $B$, shows an AII-amacrine cell in a rat retinal slice preparation filled with neurobiotin. The staining is restricted to the injected cell and did not diffuse into neighboring AII cells. Two other cell bodies of the inner nuclear layer (INL), possible bipolar cells, are weakly labeled (arrowhead, Fig. 2B); however, we think this is nonspecific uptake from the extracellular space (Kenan-Vaknin et al., 1992). Altogether, eight AII cells were filled with neurobiotin; of these, six were positively stained and in no case did we find clear tracer coupling with other AII cells or with bipolar cells. We observed one instance of extensive coupling between amacrine cells; however, neither the filled cell nor the coupled cells are AII cells (Fig. 2D). The micrograph in Figure $2 C$ shows the AII-amacrine population in the rat retina immunostained with antibodies against parvalbumin (Wässle et al., 1993). The cell bodies of AII cells form a single row along the INL/IPL border. The outer half of the IPL is well filled with their lobular appendages; their arboreal dendrites terminate close to the ganglion cell layer. Ganglion cells are also weakly labeled. It is apparent from Figure $2 C$ that AII cells are frequent and there is a good chance of hitting an AII cell body even without prelabeling.

\section{Viability of the mammalian retinal slice}

The dissection of the eye and the slicing (Werblin, 1978; Wu, 1987) causes a lot of stress to this in vitro preparation of the retina. However, we routinely found synaptic potentials and in some cases AII cells even showed light responses. Figure $3 \mathrm{~A}$ shows a whole-cell patch-clamp recording from the same AII cell that was injected with neurobiotin in Figure $2, A$ and $B$. When the microscope light was turned on for approximately 1 sec, a prominent inward current was induced (Mittman et al., 1990). Continuous spontaneous current fluctuations were also observed (Stern et al., 1992). These as well as the light response could be blocked by superfusing the slice preparation with 3 $\mathrm{mM} \mathrm{Co}^{2+}$ in the bathing medium. Figure $3 B$ shows such spontaneously occurring currents of another cell, and Figure $3 C$ shows that they can be blocked by $\mathrm{Co}^{2+}$. It is therefore likely that the current fluctuations represent postsynaptic currents evoked by spontaneous $\mathrm{Ca}^{2+}$-dependent release of transmitter from neurons that are presynaptic to amacrine cells. To avoid indirect influences from other neurons, caused by vesicular release of neurotransmitter, most of the following measurements were made in the presence of $\mathrm{Co}^{2+}$.

\section{Voltage-gated currents of AII-amacrine cells}

Voltage-gated currents were measured by the conventional patchclamp technique (Hamill et al., 1981). Having established wholecell configuration in the voltage-clamp mode, the patch-clamp amplifier was set to the current-clamp mode to measure the resting potential (zero current potential) of the cell. The range of resting potentials found was $-30 \mathrm{mV}$ to $-90 \mathrm{mV}$, and the histogram in Figure $4 A$ shows their distribution. The majority of the cells had a resting potential more negative than $-50 \mathrm{mV}$.

When depolarizing current pulses were applied, small transient depolarizations could be elicited (Fig. $4 B$ ). The cell in Figure $4 B$ was current clamped to a potential of $-68 \mathrm{mV}$. When a current of $25 \mathrm{pA}$ was injected, the cell depolarized and spikelike potentials were elicited. They could be blocked by superfusion of the slice with TTX (Fig. 4C).

This indicates that voltage-dependent $\mathrm{Na}^{+}$channels are surely involved in the generation of the spike-like potentials. However, for true $\mathrm{Na}^{+}$action potentials they were too small and too slow (duration at half-peak $>10 \mathrm{msec}$ ). In order to show that this is not due to a systematic error of our recording setup and a failure of the slice preparation in general, we used the perforatedpatch method (nystatin) (Horn and Marty, 1988) to record from a ganglion cell (Fig. $5 A$ ) and an AII-amacrine cell (Fig. $5 B$ ) in the same slice. Under these conditions it would be expected that washout of second messenger systems or of $\mathrm{Ca}^{2+}$-activated currents is minimized. The ganglion cell was depolarized from a resting potential of $-65 \mathrm{mV}$ by injection of a depolarizing current of $20 \mathrm{pA}$. At a threshold between -50 and $-40 \mathrm{mV}$, rather large action potentials of unitary size were elicited. We have also measured the activation kinetics of the $\mathrm{Na}^{+}$currents of ganglion cells (not illustrated) and, in agreement with previous reports from solitary dissociated ganglion cells of the mammalian retina, we find an activation at about $-45 \mathrm{mV}$ (Lipton and Tauck, 1987; Kaneda and Kaneko, 1991). The AII-amacrine cell (Fig. $5 B$ ) was depolarized from the resting potential of $-63 \mathrm{mV}$ by injection of a depolarizing current of $5 \mathrm{pA}$. At 

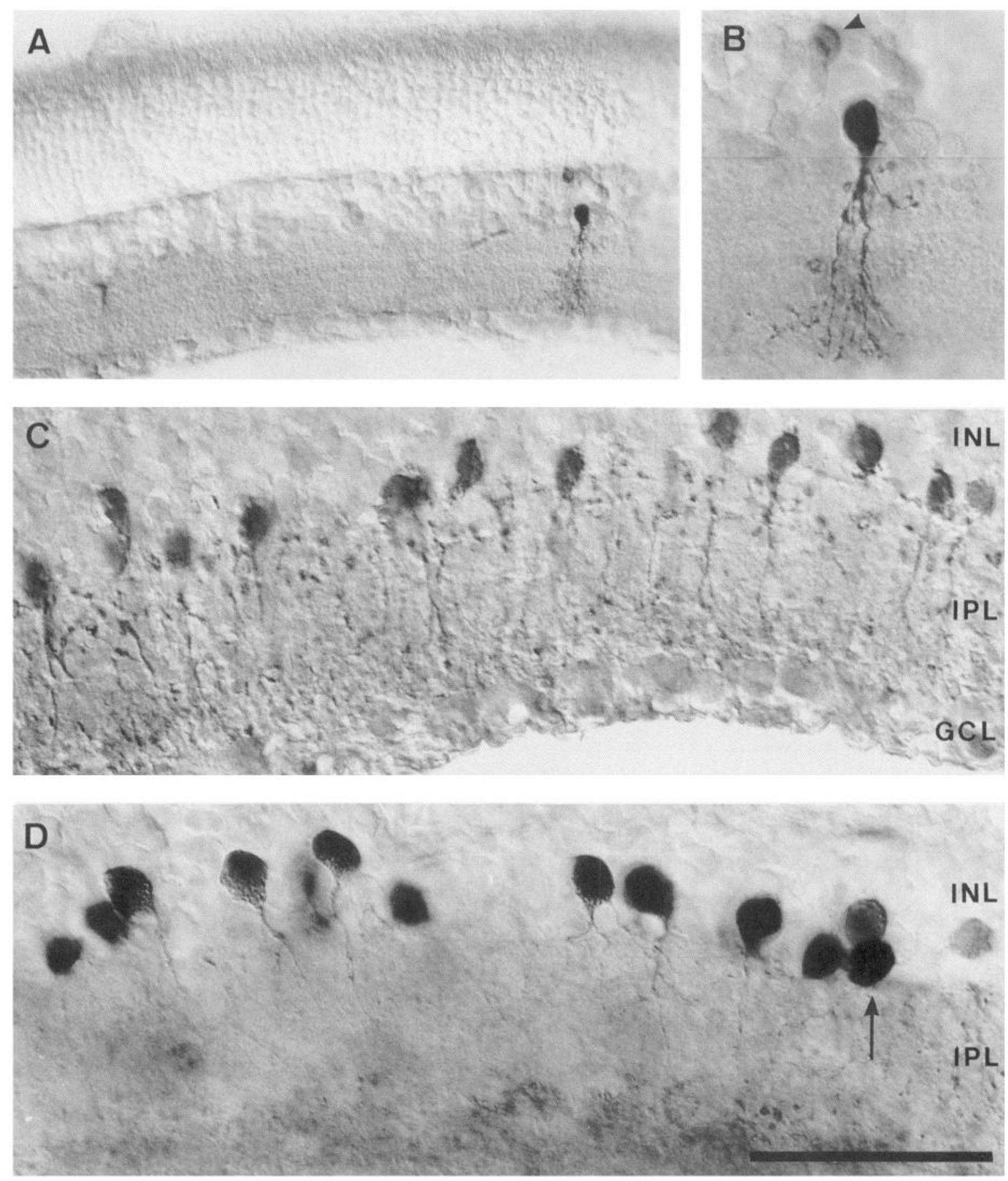

Figure 2. A, Micrograph of a rat retinal slice following neurobiotin injection into an AII-amacrine cell. The filled cell is strongly labeled and shown at higher magnification in B. A putative bipolar cell body (arrowhead) is weakly labeled. We think that the dye uptake of this bipolar cell is through damage of the axon, which passes by the AII cell body and does not represent tracer coupling. $C$, Micrograph of a frozen section through a rat retina stained for parvalbumin using the peroxidase-antiperoxidase method. The stained cells have the characteristic morphology of AIIamacrine cells: a stout descending primary dendrite, thin, short branches with lobular appendages in the outer half of the IPL and arboreal dendrites close to the ganglion cell layer $(G C L)$. Their positive identification as AII cells is presented elsewhere (Wässle et al., 1993). The micrograph demonstrates that AII-amacrine cells are found at a relatively high proportion at the INL/IPL border. $D$, Micrograph of a rat retinal slice following neurobiotin injection into the amacrine cell marked by the arrow. Many other amacrine cells are labeled by tracer coupling. Neither the filled cell nor the coupled cells are AII-amacrine cells. Scale bar: $100 \mu \mathrm{m}$ for $A, 50 \mu \mathrm{m}$ for $B-D$.

a threshold close to $-60 \mathrm{mV}$, spike-like potentials are elicited and a sustained discharge rate is observed during depolarization. Further depolarization by larger currents increased the number of spike-like potentials. The spike-like events differ in three parameters from ganglion cell action potentials: they have a lower threshold of -55 to $-60 \mathrm{mV}$ in contrast to the $-45 \mathrm{mV}$ of ganglion cells; the spike-like potentials are smaller and slower than ganglion cell action potentials; and finally, spike-like potentials are found superimposed.

In order to study the ionic currents generating the spike-like 
potentials, the voltage-gated currents of AII-amacrine cells were measured (Fig. 6). The cell was voltage clamped close to the resting potential at $-70 \mathrm{mV}$ and the voltage was stepped to more positive values for $60 \mathrm{msec}$ (Fig. $6 \mathrm{~A}$ ). A small fast inward current was followed by a large outward current. Figure $6 B$ shows the inward current in isolation. The voltage was changed from a holding potential of $-70 \mathrm{mV}$ to $-60 \mathrm{mV}$ and only the fast inward current was activated. When TTX was applied to the cell (Fig. $6 B$ ) the fast inward current was completely blocked; hence, it is likely to be a voltage-dependent $\mathrm{Na}^{+}$current (Hille, 1992). The same fast transient currents were also recorded when $3 \mathrm{mM} \mathrm{Co}^{2+}$ was added to the bathing medium in order to block $\mathrm{Ca}^{2+}$ currents and synaptic activity. They were found in $\mathbf{4 5}$ out of 49 AII cells tested. TTX was applied to nine cells and always blocked the fast inward currents.

The characteristics of this current were measured from the current-voltage curves. However, as mentioned in Materials and Methods, the input capacitance of AII cells is large and the capacitative transients do not decay along a simple exponential time course. Moreover, since many cells were lost when the series resistance compensation was turned on, the following measurements were done without that compensation. Due to the series resistance, the voltage clamp might not be as effective as needed, and because the cell has many processes, these might not be isopotential. Hence, there is an obvious problem of space clamp in the following measurements. Figure $7 A$ shows the current-voltage curve of the TTX-sensitive current in an AII-amacrine cell, which was voltage clamped at a holding potential of $V_{H}=-90 \mathrm{mV}$. At different command voltages the peak amplitude of the fast transient inward current was measured. $\mathrm{K}^{+}$ outward currents were suppressed by TEA and $\mathrm{Cs}^{+}$in the patch pipette. The TTX-sensitive current activated between -65 and $-60 \mathrm{mV}$; however, the steep slope of activation of the current and the gentle slope of the fully activated current in Figure $7 \mathrm{~A}$ are affected by the problem of space clamp. The activation at low voltages $(<-60 \mathrm{mV})$ seems to be a characteristic of the voltage-dependent $\mathrm{Na}^{+}$current of the AII cells. In ganglion cells, as mentioned before, we consistently found an activation at -45 $\mathrm{mV}$ for the $\mathrm{Na}^{+}$currents.

It was possible to inactivate this current by different prepotentials. This is shown in Figure $7 B$ for another AII-amacrine cell. The cell was held at $-90 \mathrm{mV}$, then prepotentials $\left(V_{p}\right)$ of 60 msec duration and variable height were applied. After a brief reset pulse (duration, $1 \mathrm{msec}$ ) the command voltage (duration, $30 \mathrm{msec}$ ) was set at $V_{c}=-40 \mathrm{mV}$ and the peak of the fast transient inward current was measured. It can be seen in Figure $7 B$ that steady state inactivation occurs already at $V_{p}=-80$ $\mathrm{mV}$, and at $V_{p}=-30 \mathrm{mV}$ this current is completely suppressed.

The prominent outward current of Figure $6 A$ quite likely is caused by activation of voltage-dependent $\mathrm{K}^{+}$channels. In Figure 8 the influence of TEA and of 4-AP on these channels is illustrated. The outward current (Fig. $8 A$ ) has a phasic/tonic characteristic. Bath application of TEA strongly reduces the current (Fig. $8 B$ ); bath application of 4-AP has only little effect (Fig. $8 C$ ). When TEA and 4-AP are applied together (Fig. $8 D$ ) most of the current is blocked. With $\mathrm{Cs}^{+}$and TEA in the electrode solution (not shown) a complete block of the outward current could be achieved.

The voltage dependence of the outward current is displaycd separately for the peak (Fig. $9 A$ ) and the sustained component (Fig. 9B). The original data and the data corrected for the series resistance are shown. The currents activate at approximately
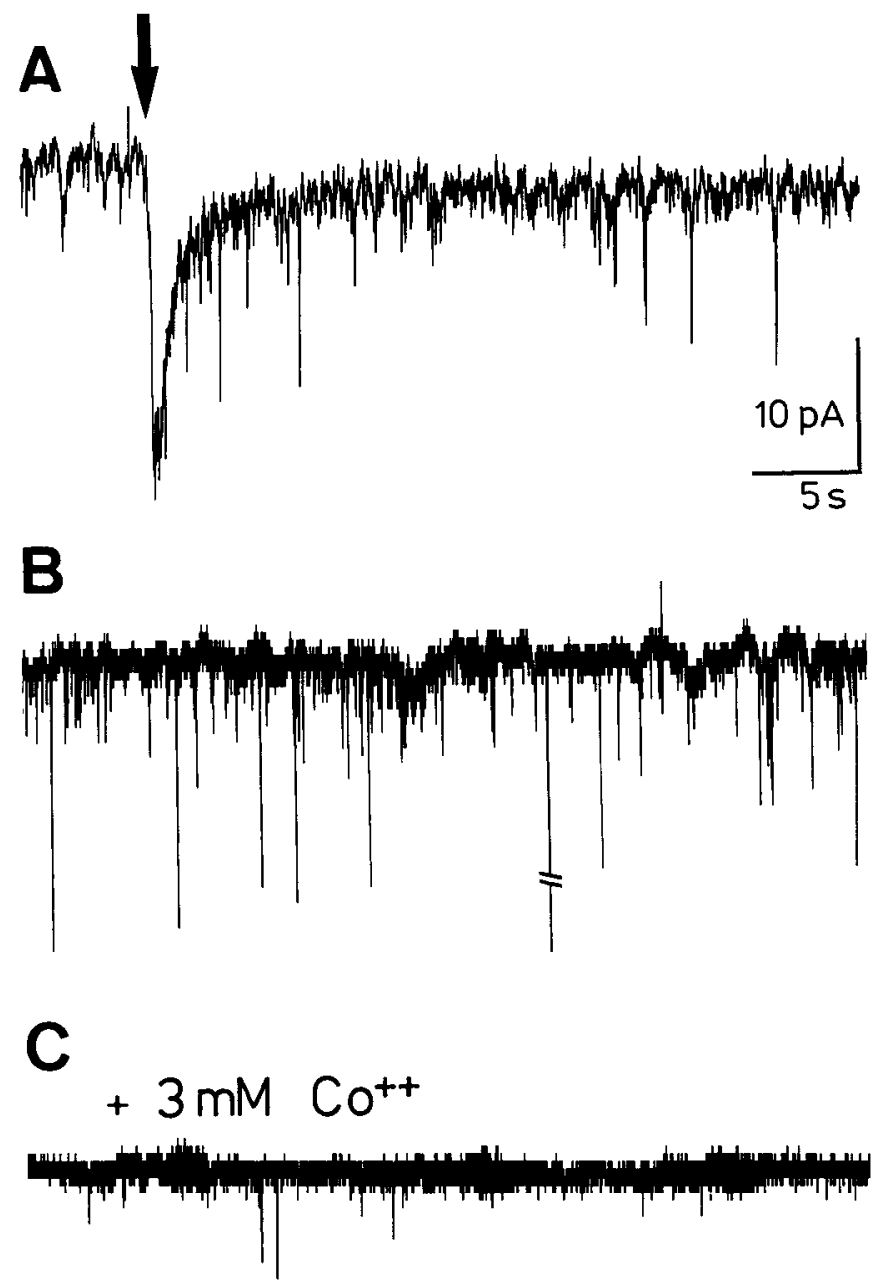

Figure 3. A, Whole-cell currents recorded from an AII-amacrine cell during voltage clamp. This is the same AII-cell that was injected with neurobiotin and is shown in Figure $2 A$. The cell was clamped close to the resting potential at $V_{H}=-60 \mathrm{mV}$. Many spontaneously occurring putative postsynaptic currents can be scen. At the time indicated by the arrow the translucent illumination of the microscope was turned on for approximately $l \mathrm{sec}$, and a distinct inward current was elicited. $B$, Whole-cell currents of another cell that was voltage clamped at $V_{H}=$ $-60 \mathrm{mV}$. Many spontaneous putative postsynaptic currents can be detected. These are blocked when $3 \mathrm{mM} \mathrm{Co}^{2+}$ is added to the bathing medium, as shown in $C$.

$-50 \mathrm{mV}$ and the peak component shows a steeper slope than the sustained component. Because of the relatively high uncompensated series resistance, at a given command voltage the phasic component is more strongly attenuated than the tonic component, and is underestimated in Figures 6 and 8 .

The steady state inactivation of the currents is shown in Figure $9 C$. The tonic component does not seem to inactivate by the prepotentials, while the transient component is inactivated by prepotentials of $-30 \mathrm{mV}$.

Although application of 4-AP and TEA did not dissect two such components, steady state inactivation mainly influenced the transient peak. Hence, it is possible that two separate types of $\mathrm{K}^{+}$channel contribute to the outward current (Klumpp et al., 1991; Salkoff et al., 1992).

In summary one can conclude that AII-amacrine cells show spike-like potentials when their membrane is depolarized. It is very likely that voltage-dependent $\mathrm{Na}^{+}$and $\mathrm{K}^{+}$currents are 

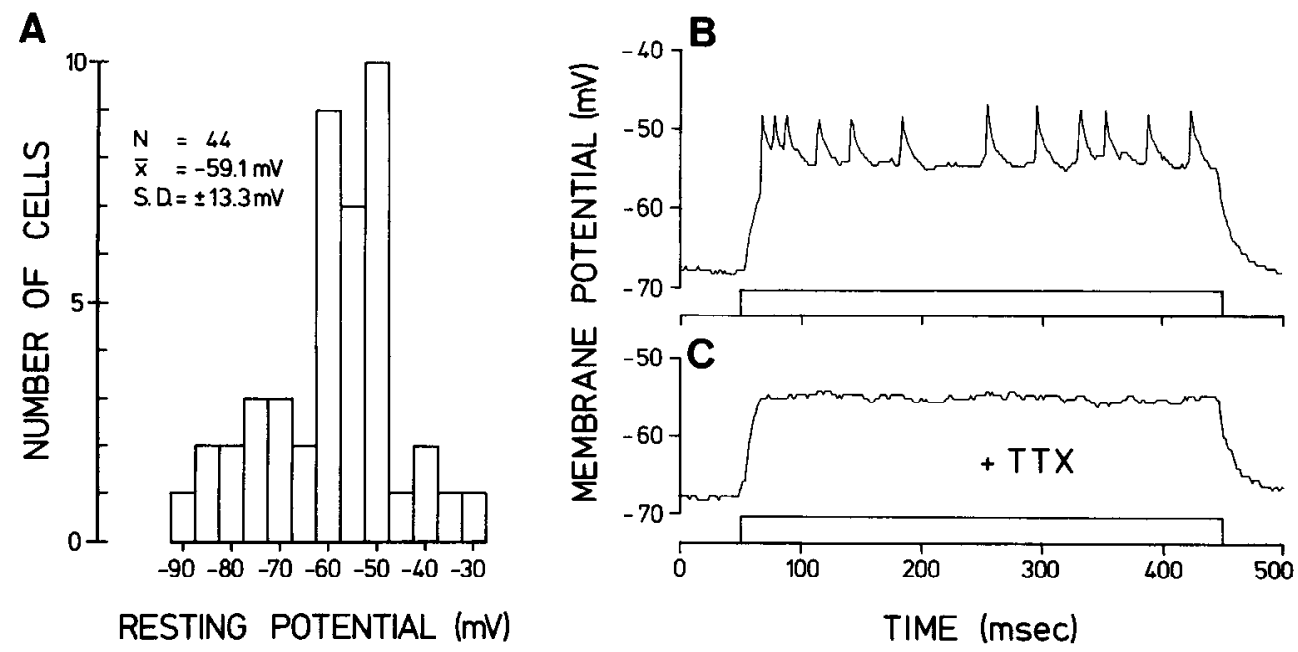

Figure 4. A, Distribution of resting potentials of AII-amacrine cells measured at the beginning of the recordings in the current-clamp mode (zero current). The mean resting potential was found to be $-59.1 \pm 13.3 \mathrm{mV}(N=44) . B$, Voltage response of an AII-amacrine cell upon injection of current. The resting potential of the cell was $48 \mathrm{mV}$, and the holding potential was $V_{H}=68 \mathrm{mV}$. A depolarizing current of $25 \mathrm{pA}$ (horizontal line above the abscissa) elicited spike-like potentials at a threshold of -60 to $-55 \mathrm{mV}$. The amplitude of the spikes was quite small $(<10 \mathrm{mV})$. When more current was injected, the frequency of the spikes increased and a sustained discharge rate was observed. Small currents depolarized the cell without eliciting spike-like potentials. $C$, When the slice was superfused with TTX, applied at a concentration of $1 \mu \mathrm{M}$ from the puffer pipette, the spike-like potentials were blocked. Current injection was $30 \mathrm{pA}$ (bath solution E2, electrode solution I1).

involved in the generation of these small spike-like potentials. However, the precisc kinctics and relative sizes of the underlying currents, and where on the AII cells they are localized, need further investigation.

No attempts were made in the present study to isolate or investigate voltage-activated $\mathrm{Ca}^{2+}$ currents.

\section{Ligand-gated currents of AII-amacrine cells}

It is very likely that bipolar cells of the mammalian retina use glutamate as their transmitter (Bloomfield and Dowling, 1985; Massey and Miller, 1988; Massey, 1990). It has been shown that glycine and GABA are transmitter substances of the majority of mammalian amacrine cells (for review, see Massey and
Redburn, 1987; Vaney, 1990), but there is also a distinct population of cholinergic amacrinc cells (Masland, 1986; Voigt, 1986). In order to test whether AII-amacrine cells have receptors in their membranes for these four transmitter substances, wholecell currents were measured upon application of related compounds. Cobalt was added to the bathing medium, which was shown in Figure $3 C$ to block vesicular synaptic release of transmitter from presynaptic neurons. The perforated-patch method (nystatin) was used to minimize washout of second messenger systems that are critical for activation of APB-gated currents (Nawy and Jahr, 1991; Yamashita and Wässle, 1991a,b; Shiells and Falck, 1992a,b). Figure 10 shows whole-cell currents elicited by application of KA, muscimol (MUSC), glycine (GLY), L-APB,
A

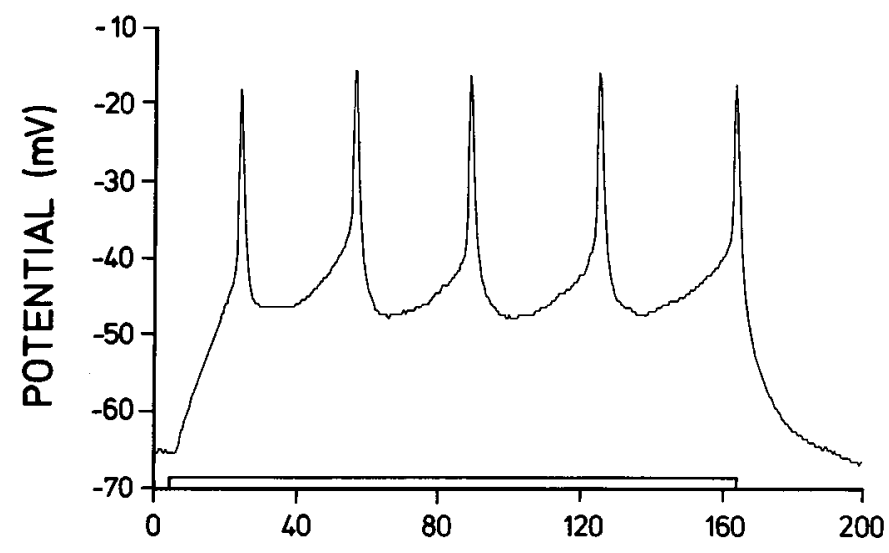

B

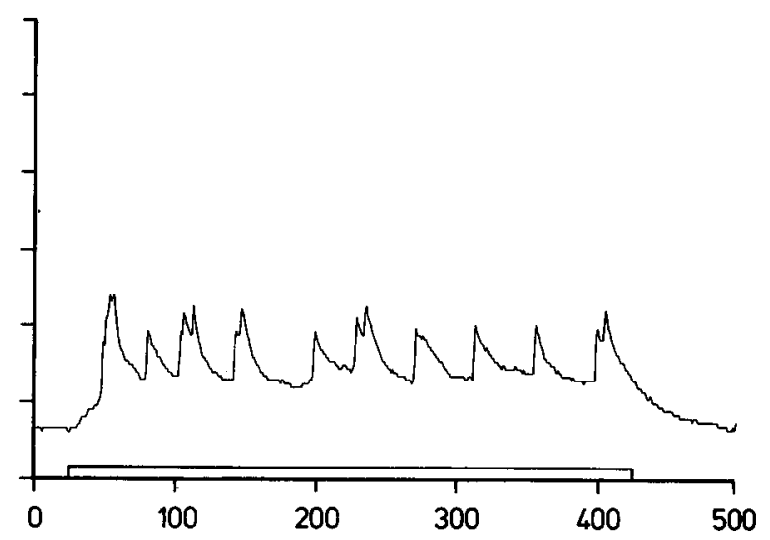

\section{TIME (msec)}

Figure 5. Recordings from a ganglion cell $(A)$ and from an AlI-amacrine cell $(B)$ that were current clamped at their resting potentials. $A$, Rather large action potentials are elicited by injecting a depolarizing current of $20 \mathrm{pA}$ through the patch pipette into a ganglion cell. $B$, Small spike-like potentials were elicited when a current of 5 pA was injected into an AII-amacrine cell. Please note the superposition of spike-like potentials (bath solution E2, electrode solution I1 + nystatin). 
$\mathbf{A}$

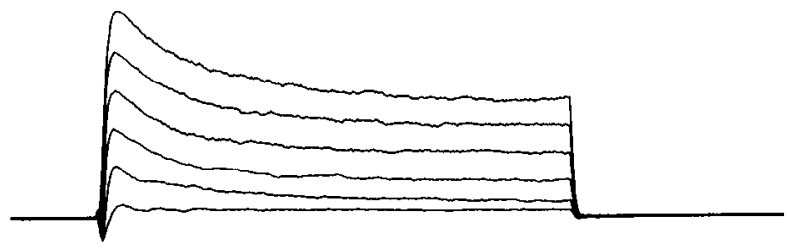

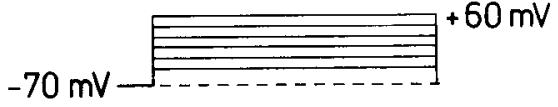

B

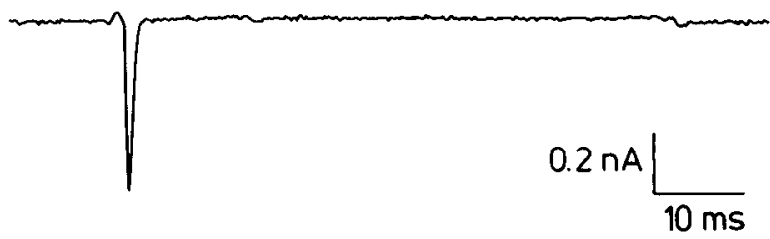

$1 \mu M$ TTX

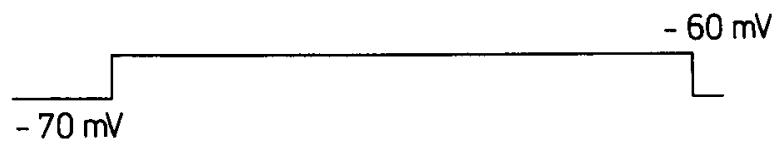

Figure 6. A, Whole-cell currents recorded from an AII-amacrine cell during voltage clamp. From a holding potential of $-70 \mathrm{mV}$ the voltage was stepped to $-40,-20,0,+20,+40$, and $+60 \mathrm{mV}$ (electrode solution $\mathrm{I} 1$, bath solution $\mathrm{E} 2$ ). $B$, The same AII-amacrine cell is depolarized from $-70 \mathrm{mV}$ to $-60 \mathrm{mV}$, which activated only the fast transient inward current. $C$, Superfusion of the cell with TTX (concentration in the puffer pipette, $1 \mu \mathrm{M}$ ) blocked the transient inward current. The bottom trace shows the voltage protocol (no leakage substraction applied).

and ACh. A prominent inward current was induced by the glutamate agonist KA, but no response was measured when APB was applied. Muscimol, a $\mathrm{GABA}_{\mathrm{A}}$-receptor agonist, and glycine induced strong inward currents, while $\mathrm{ACh}$ application had practically no effect. The currents upon application of muscimol and glycine were recorded after perfusion of the cell with the $\mathrm{Cl}^{-}$solution of the electrode, that is, under symmetrical $\mathrm{Cl}^{-}$ concentrations of $137 \mathrm{~mm}$ inside and outside. Under these conditions $\left(E_{\mathrm{Cl}}\right.$ near $\left.0 \mathrm{mV}\right)$ an inward current was measured at $V_{H}$ $=-70 \mathrm{mV}$. The transmitter effects were also tested in the current-clamp mode (Fig. 11). A cell clamped at the resting potential (zero current) was strongly depolarized by KA and glutamate (GLU), while $\Lambda$ PB had no effect. Muscimol and glycine, as well as taurine (TAU), also caused depolarizations of the membrane potential (symmetrical $\mathrm{Cl}^{-}$!). At the limited time resolution of Figure 11, no spike-like potentials can be detected upon depolarization of AII cells by, for instance, glutamate. However, at better resolution spike-like potentials similar to those elicited by current injection could be detected (not shown).

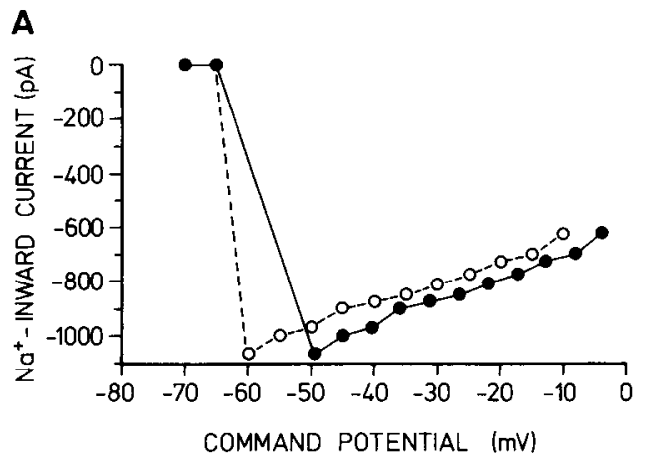

\section{Characterization of ligand-gated currents of AII-amacrine cells}

The results upon application of muscimol, glycine, and taurine shown in Figures 10 and 11 were recorded with symmetrical $\mathrm{Cl}^{-}$concentrations. Under those circumstances the currents reversed at $0 \mathrm{mV}$ holding potential. When the $\mathrm{Cl}^{-}$concentration in the electrode was lowered, the reversal potential followed the prediction of the Nernst equation for $\mathrm{Cl}^{-}$and we conclude that muscimol as well as glycine and taurine gate $\mathrm{Cl}^{-}$conductances. The equilibration of $\mathrm{Na}^{+}$and $\mathrm{K}^{+}$ions through the perforated patch is about 10 times faster than that of $\mathrm{Cl}^{-}$ions (Horn and Marty, 1988). Therefore, the interior $\mathrm{Cl}^{-}$concentration is close to the intact value just after the pore formation by nystatin. When muscimol or glycine were applied during this initial period they caused hyperpolarization of AII-amacrine cells in the current-clamp mode and an outward current when the cells were voltage clamped at the resting potential (not shown). After a few minutes the polarities reversed because of $\mathrm{Cl}^{-}$equilibration

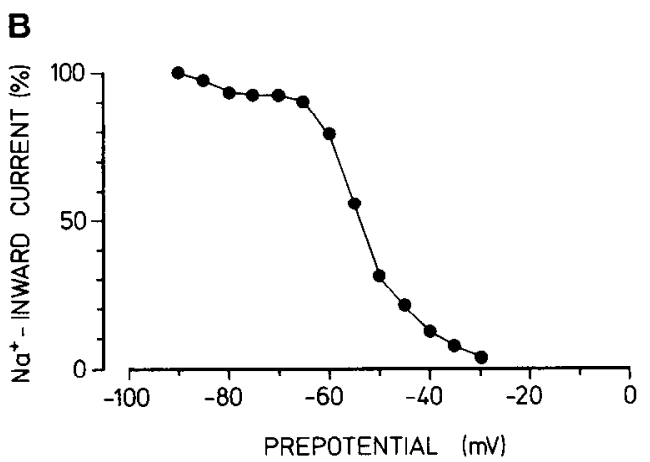

Figure 7. Current-voltage curves for the voltage-dependent $\mathrm{Na}^{+}$current. $A$, Peak amplitude of the inward current in response to voltage steps of $60 \mathrm{msec}$ duration $\left(V_{H}=-90 \mathrm{mV}\right)$. The open circles and the dashed curve show the amplitudes measured. The solid circles and the solid line show the current-voltage relation corrected for the measured series resistance $(10 \mathrm{M} \Omega$ ). The inward current activates between -65 and $-60 \mathrm{mV}$ (electrode solution I2, bath solution E2). B, The abscissa gives the voltage of the conditioning prepotential (duration $60 \mathrm{msec}$ ). The ordinate shows the peak amplitude of the fast transient inward current measured after this prepotential at a command voltage of $-40 \mathrm{mV}$. Between -85 and $-80 \mathrm{mV}$ steady state inactivation starts and at $-30 \mathrm{mV}$ this inward current is completely inactivated. 
A

Figure 8. Voltage-dependent $\mathrm{K}^{+}$currents of AII-amacrine cells. $A$, The cell was voltage clamped at $-70 \mathrm{mV}$ and voltage was stepped to $-60,-40,-20$, $0,+20,+40$, and $+60 \mathrm{mV}$ for $60 \mathrm{msec}$ (electrode solution I1, bath solution E2). An outward current with a phasic/tonic characteristic was elicited. $B$, Application of TEA from the puffer pipette ( 25 mM) effectively reduced this outward current. $C$, Application of 4-AP (10 mM) had only a slight effect. $D$, Application of TEA and 4-AP strongly suppressed the outward current. There was no need to apply TTX to this cell, because the $\mathrm{Na}^{+}$inward current was very small. In other cells where TTX was applied, it blocked the fast inward current without significant effects on the outward currents. The traces at the bottom show the voltage protocols applied.

B
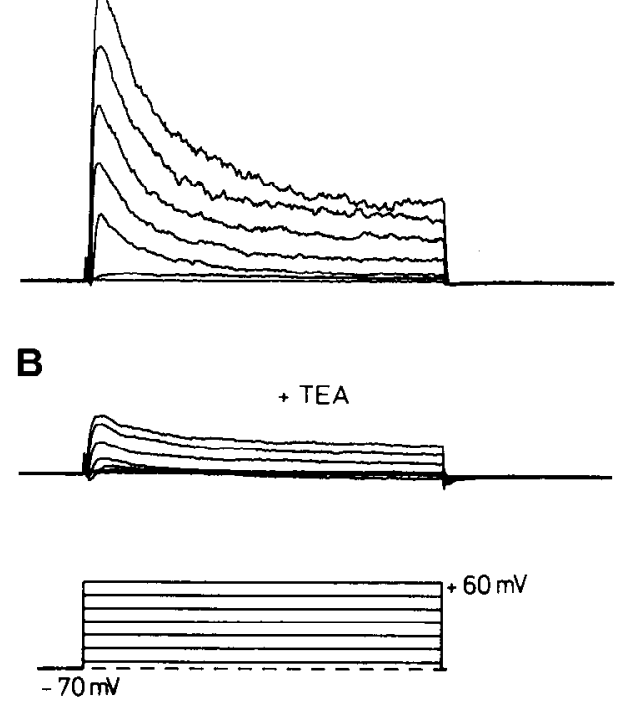

C

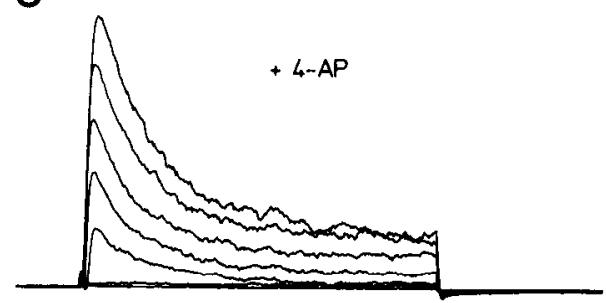

D

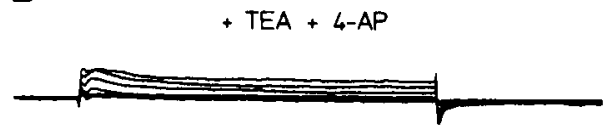

$0.4 \mathrm{nA} \bigsqcup_{10 \mathrm{~ms}}$
(Yamashita and Wässle, 1991a). From this result we conclude that for intact AII-amacrine cells the $\mathrm{Cl}^{-}$reversal potential is more negative than the resting potential. GABA and glycine thus would hyperpolarize AII-amacrine cells in situ. The actions of glycine and taurine (not shown) could be blocked by coapplication of strychnine (STRY), suggesting that both act on a conventional strychnine-sensitive glycine receptor (Fig. 12A). The glycine-induced currents showed a fast peak followed by a sustained plateau (Figs. 10, 12), which suggests a rapid desensitization of the receptor (Bormann, 1990). The glycine effects were not blocked by coapplication of bicuculline (BIC) (Fig. $12 B)$.

Muscimol, the $\mathrm{GABA}_{\mathrm{A}}$-receptor agonist, induced a prominent current in all AII-amacrine cells. The current showed a transient/sustained characteristic. Figure $12 B$ shows the actions of muscimol and glycine and their interaction with bicuculline. Only the muscimol-induced current was effectively blocked by bicuculline. When GABA was used instead of muscimol, a comparable reduction was observed by application of bicuculline. We therefore conclude that GABA activates a $\mathrm{Cl}^{-}$conductance in AII-amacrine cells through $\mathrm{GABA}_{\mathrm{A}}$-type receptors (Ishida, 1992).

The following agonists at excitatory amino acid (EAA) receptors (Watkins et al., 1990) were tested on AII-amacrine cells: glutamate, KA, quisqualate, NMDA, and APB. While glutamate, KA, and quisqualate induced prominent currents, NMDA and APB were ineffective. Because NMDA receptors are blocked by $\mathrm{Mg}^{2+}$ ions, show strong voltage dependence, and are augmented by coapplication of glycine, different conditions were used to test for the effects of NMDA (Mayer and Westbrook, 1987; Ascher et al., 1988). Low $\left[\mathrm{Mg}^{2+}\right]$, addition of $0.5 \mu \mathrm{M}$ glycine, and/or more positive holding potentials did not unmask an NMDA-gated current in AII-amacrines (Fig. 13A,B). It is therefore unlikely that NMDA receptors make an important contribution to the EAA-induced currents of AII cells. Under comparable conditions we found NMDA responses in other types of amacrine cells and in ganglion cells; hence, we exclude the possibility that a methodological problem might be responsible for not finding them in AII-amacrine cells.
Glutamate, KA, and AMPA induced prominent responses when applied to AII-amacrine cells (Fig. 13A,B). As shown in Figure $13 D$, the KA- and AMPA-induced inward currents could be blocked completely by coapplication of CNQX. The reversal potential of these currents was close to $0 \mathrm{mV}$. Hence, $\mathrm{KA}$ and AMPA very likely gate nonselective cation channels with $\mathrm{Na}^{+}$ ions as the main charge carrier at the holding potential of -70 $\mathrm{mV}$. Since CNQX is an antagonist at both the KA- and AMPAtype of receptors (Watkins et al., 1990), we could not further characterize these EAA receptors of AII cells.

As described before (Figs. 10, 11), APB had no effect on the majority of AII-amacrine cells. Altogether, 10 cells were tested for APB responses, all with nystatin in the electrode. In only three cases were APB responses measured; however, these disappeared when $\mathrm{Co}^{2+}$ was added to the bathing medium (Fig. 14). Hence, we conclude that APB has no direct effect on AIIamacrine cells. In contrast, all cells tested showed prominent inward currents $\left(V_{H}=-70 \mathrm{mV}\right)$ when $\mathrm{KA}$, glutamate, or AMPA were applied. Therefore, if glutamate is the transmitter released by rod bipolar cells, it will cause depolarization of AII-amacrine cells, and the synapse between rod bipolars and AII-amacrine cells is a sign-conserving synapse.

\section{Discussion}

\section{Electrical coupling of AII-amacrine cells}

AII-amacrine cells of the cat, rabbit, and rat retinas have been reconstructed from electron microscopic serial reconstructions and it has been reported that they make two types of gap junctions (Famiglietti and Kolb, 1975; Kolb, 1979; Sterling, 1983; Strettoi et al., 1992; Chun et al., 1993). On the descending shaft they have large gap junctions with ON-cone bipolar cells. These gap junctions display an asymmetric structure with a layer of fluffy material underlying the cytoplasmatic aspect of the AII cell membrane (Kolb, 1979; Strettoi et al., 1992). The vitral dendrites of neighboring AII-amacrine cells are connected by small, symmetrical gap junctions.

What is known about the functional role of these gap junctions, how are they modulated by the light or dark adaptation of the eye, and how do they influence the interpretation of the 
present results? Extensive coupling using neurobiotin as a tracer was recently observed in vitro between rabbit AII-amacrinc cclls as well as between AII-amacrine cells and cone bipolar cells (Vaney, 1991). Coupling could be greatly reduced by dopamine acting on $D_{1}$ receptors (Hampson et al., 1992). Similar uncoupling by dopamine has been shown previously for horizontal cells of the vertebrate retina (for review, see Dowling, 1991; Witkovsky and Dearry, 1991). AII-amacrine cells receive many synapses from dopaminergic amacrine cells. Most of these synapses are at the cell body or the primary dendrites (Pourcho, 1982; Voigt and Wässle, 1987; Kolb et al., 1990), and dopaminergic processes form ring-like structures surrounding the perikarya of AII cells. Hence, it is conceivable that in vivo AII cell coupling is under dopaminergic control. Dopamine release in the mammalian retina is greater in light-adapted tissue (Parkinson and Rando, 1983; Godley and Wurtman, 1988; Witkovsky and Dearry, 1991); therefore, it can be expected that AII cells are uncoupled in light-adapted retinas.

The retinal slice preparation of the present study was light adapted and this might be the reason why AII cells were not coupled (Fig. $2 A$ ). The weak staining of a few bipolar cell bodies close to the injected AII cell body very likely is caused by uptake of neurobiotin through their axons passing by the AII cell body. Labeled bipolar cell bodies are restricted to a narrow column above the injected AII cell body and do not form the regular, widely spaced mosaic described by Vaney (1991) for tracercoupled ON-cone bipolar cells. However, there is also a pharmacological reason why we think AII cells and ON-cone bipolar cells are not electrically coupled in our preparation. It is well known that APB acts as an agonist of the photoreceptor transmitter when applied to ON-bipolar cells (Slaughter and Miller, 1981; Massey et al., 1983; Bolz et al., 1984) and hyperpolarizes the cells by closing nonspecific cation channels (Nawy and Jahr, 1991; Shiells and Falck, 1992b). Hence, were the ON-conc bipolar cells electrically coupled to AII-amacrine cells, application of APB should hyperpolarize AII-amacrine cells. This seems not to be the case in the slices of the present study. APB was applied onto $10 \mathrm{AII}$ cells. In only three cases were APB responses measured; however, they were blocked by $\mathrm{Co}^{2+}$ added to the bathing medium. It is very likely that these effects of APB are due to the rod bipolar input into AII cells, and $\mathrm{Co}^{2+}$ blocks the vesicular, $\mathrm{Ca}^{2+}$-dependent synaptic transmission between rod bipolars and AII cells (Tachibana and Okada, 1991). Although this APB experiment does not exclude the possibility of unidirectional current flow from AII cells into ON-cone bipolars, the lack of tracer coupling makes this unlikely. In conclusion, AII cell gap junctions seem to be closed in our slice preparation and, more generally, they seem to be closed in the light-adapted retina.

\section{Voltage-gated currents of AII-amacrines}

When Cajal introduced the name "amacrine cell," he wanted to direct attention to the fact that such cells have no axon. This is certainly true for AII-amacrine cells, but might not be so for many wide-field amacrines (reviewed in Vaney, 1990). AIIamacrine cells in the rat have small dendritic fields and the maximum distance from the cell body to the finest dendritic tips is less than $100 \mu \mathrm{m}$. In the inner part of the IPL, where they receive input from rod bipolar cells, they have a bushy dendritic field; in the outer part of the IPL, AII-amacrines have thin, short dendrites that terminate in rather large swellings, the so-called lobular appendages (Fig. 1D). Given this rather com-
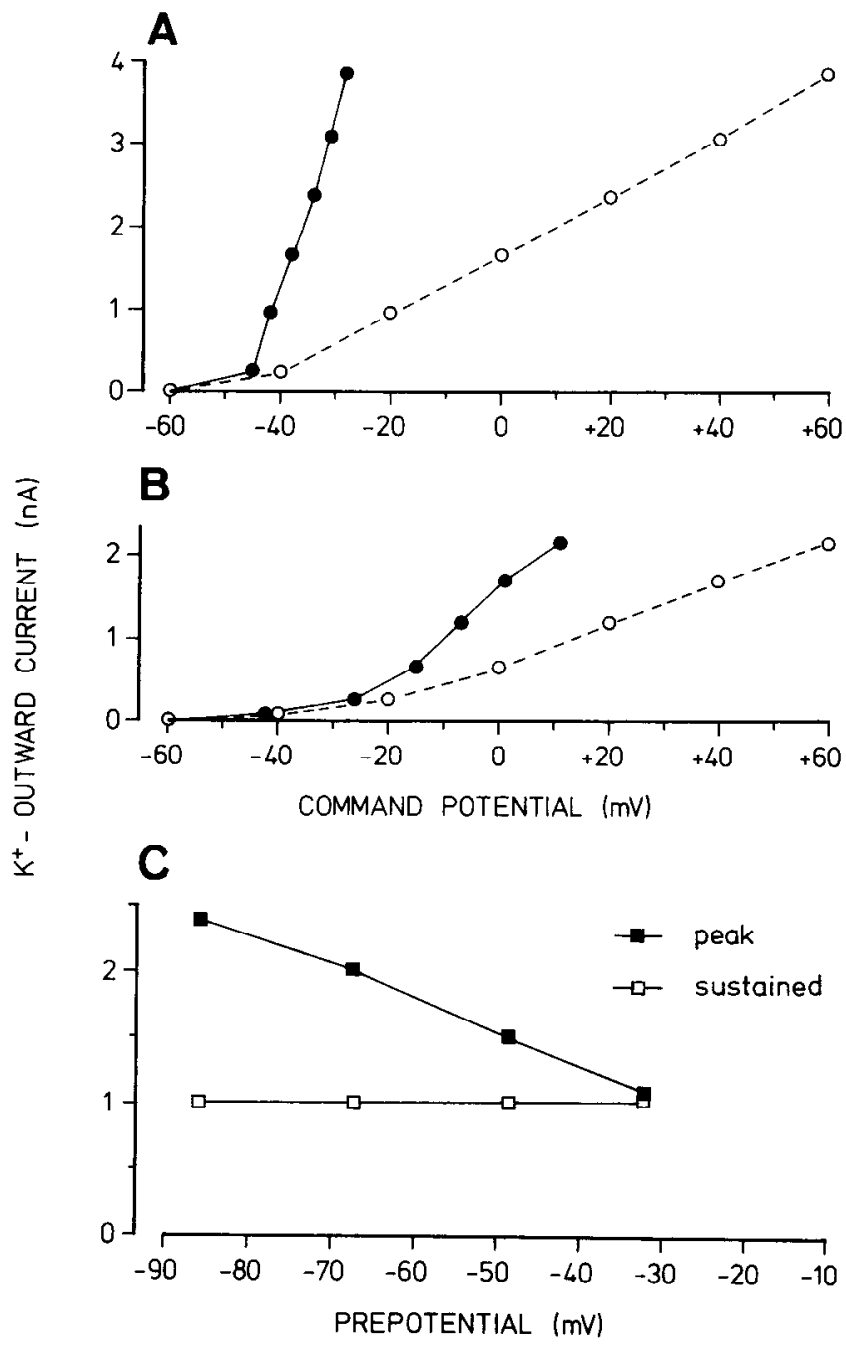

Figure 9. Current-voltage curves for the voltage-dependent $\mathrm{K}^{+}$currents elicited in response to voltage steps of $60 \mathrm{msec}$ duration $\left(V_{H}=\right.$ $-90 \mathrm{mV}$ ). A, Voltage dependence of the peak response. The open circles and the dashed line show the amplitudes measured. The solid circles and the solid line show the current-voltage relation corrected for the measured series resistance ( $23 \mathrm{M} \Omega$ ). $B$, Voltage dependence of the sustained response, which was measured $55 \mathrm{msec}$ after depolarization (other conventions as in $A$ ). $C$, Steady state inactivation of the peak current (solid squares) and of the sustained current (open squares). After a conditioning prepotential of $60 \mathrm{msec}$ duration (shown on the abscissa), the currents elicited by a test potential of $+40 \mathrm{mV}$ were measured. The sustained current is not inactivated by the prepotential, while the peak current decreases. At a prepotential of $-30 \mathrm{mV}$ the curves meet, indicating that the phasic component of the response is completely inactivated.

pact dendritic field, there is no need to conduct impulses for long distances, and it is very likely that the voltage-gated channels described in the present study subserve a different function.

As mentioned before, we faced great difficulties in characterizing these voltage-gated channels because of problems with the space clamp. Although AII-amacrine cells are rather small neurons, we measured an input capacitance up to $10 \mathrm{pF}$, which is more than twice that of other amacrines in rat retina slices. In addition, the capacitative currents did not decay along a single exponential. We also had difficulties in compensating the series resistance. It is possible that the voltage-activated channels of AII cells are found not on the soma but on the dendrites, such 
Figure 10. Whole-cell currents recorded from an AII-amacrine cell that was voltage clamped at $V_{H}=-70 \mathrm{mV}$. The bars show the time when the drugs were applied through the puffer pipette (bath solution E3, electrode solution I1 + nystatin). See Results for more details.

as the lobular appendages, which may act as isolated compartments. TTX-sensitive dendritic spikes have also been reported for amacrine cells of the mudpuppy retina (Miller and Dacheux, 1976) and in neocortical pyramidal cell dendrites (Stuart and Sakmann, 1992). Such a distribution of TTX-sensitive $I_{\mathrm{Na}}$ in isolated compartments might be responsible for our problems with the space clamp and for the superposition of the spike-like potentials. There is some circumstantial evidence to support this. Sometimes we recorded from AII-amacrines from which most of the dendrites were cut off during the slicing procedure. Such cells appeared to be healthy with a normal input resistance but did not show spike-like potentials.

Another unusual feature of the voltage-gated channels found on AII cells is their low activation at -55 to $-60 \mathrm{mV}$, in contrast

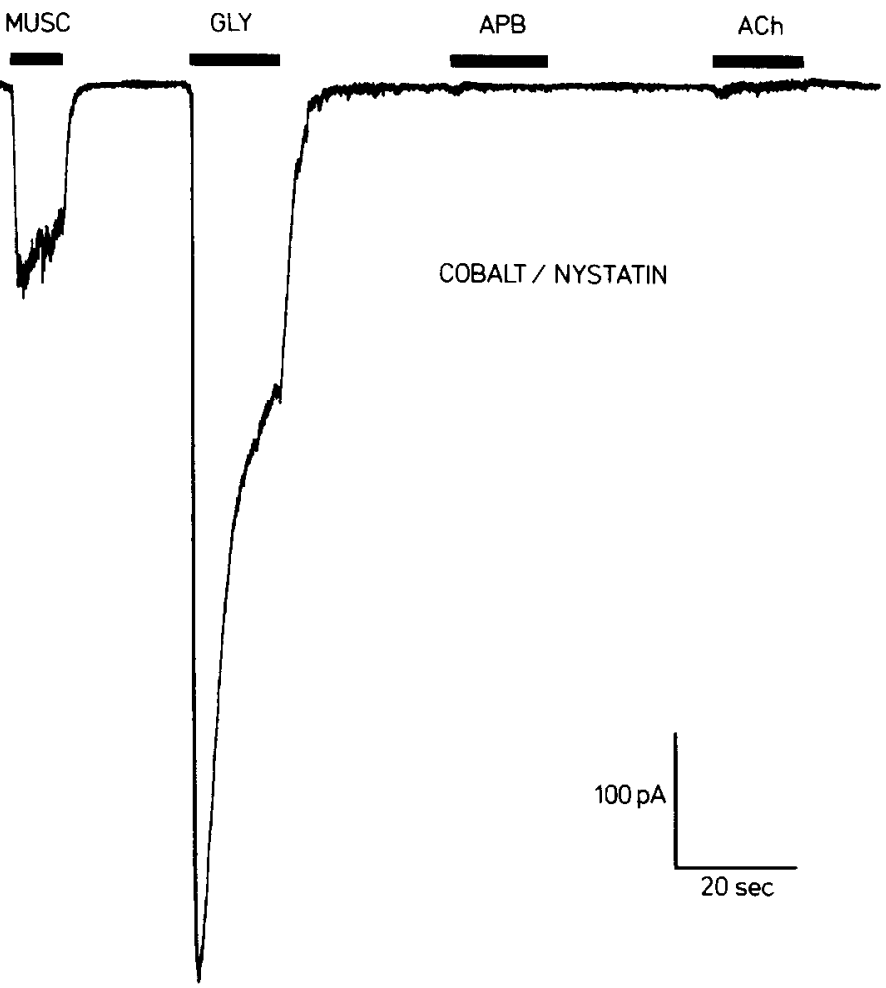

to ganglion cells, where sodium currents first appeared at -45 $\mathrm{mV}$. The experiment where we depolarize a ganglion cell (Fig. $5 A$ ) and an AII cell from identical resting potentials by current injection shows this difference in activation threshold quite convincingly. It is therefore possible that two different types of $\mathrm{Na}^{+}$ channels are expressed in AII and ganglion cells (Stühmer et al., 1989; Patlak, 1991).

What might be the function of the voltage-gated channels in AII cells? Intracellular recordings of AII-amacrine cell light responses are available from the cat (Nelson, 1982) and from the rabbit retina (Dacheux and Raviola, 1986). These studies noted that the time course of the initial phase of AII light responses is much faster than that of rod bipolar cells, which provide the input. In rabbit retina (Dacheux and Raviola, 1986), small spike-
Figure 11. Voltage changes induced in an AII-amacrine cell by application of different drugs. The cell was current clamped at the resting potential (bath solution E2, electrode solution $\mathrm{I} 1+$ nystatin). See Results for more details.

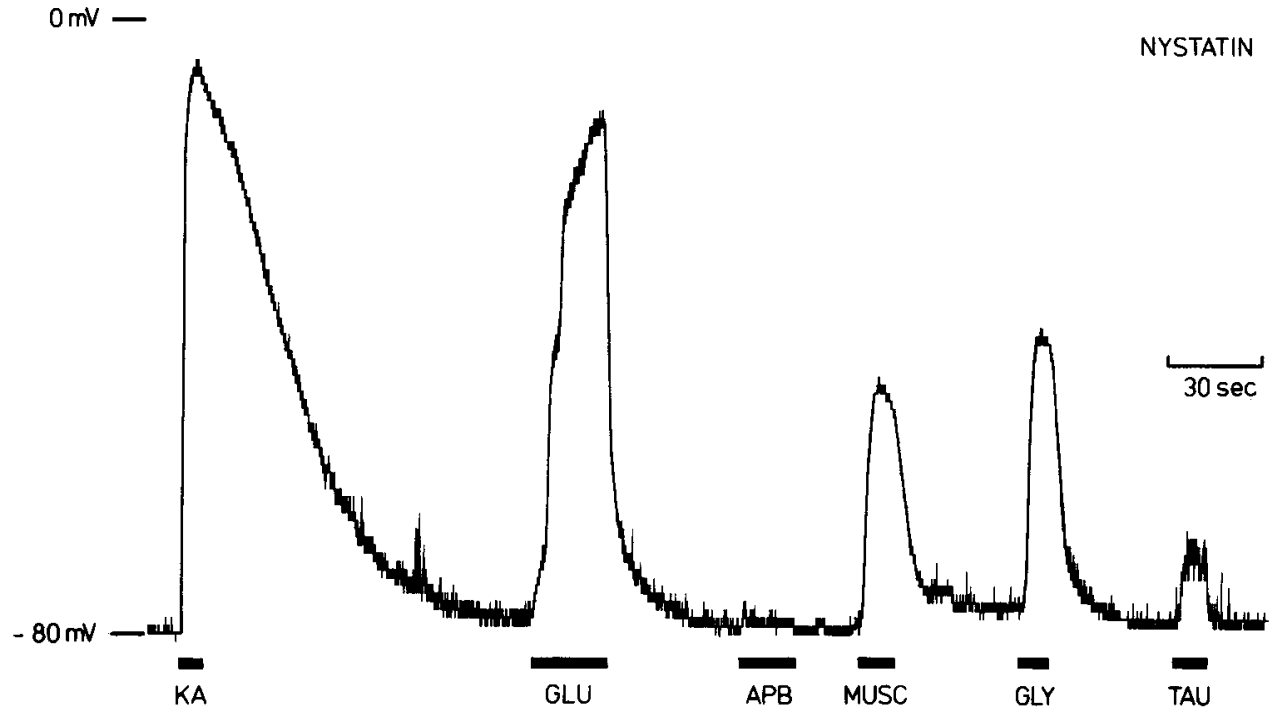


A

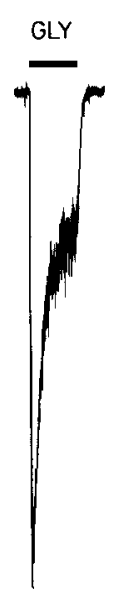

like potentials were found in the initial phase of AII light responses. We think that the opening of the voltage-dependent $\mathrm{Na}^{+}$channels is responsible for the acceleration of the light response. The spike-like potentials recorded in rabbit AII cells
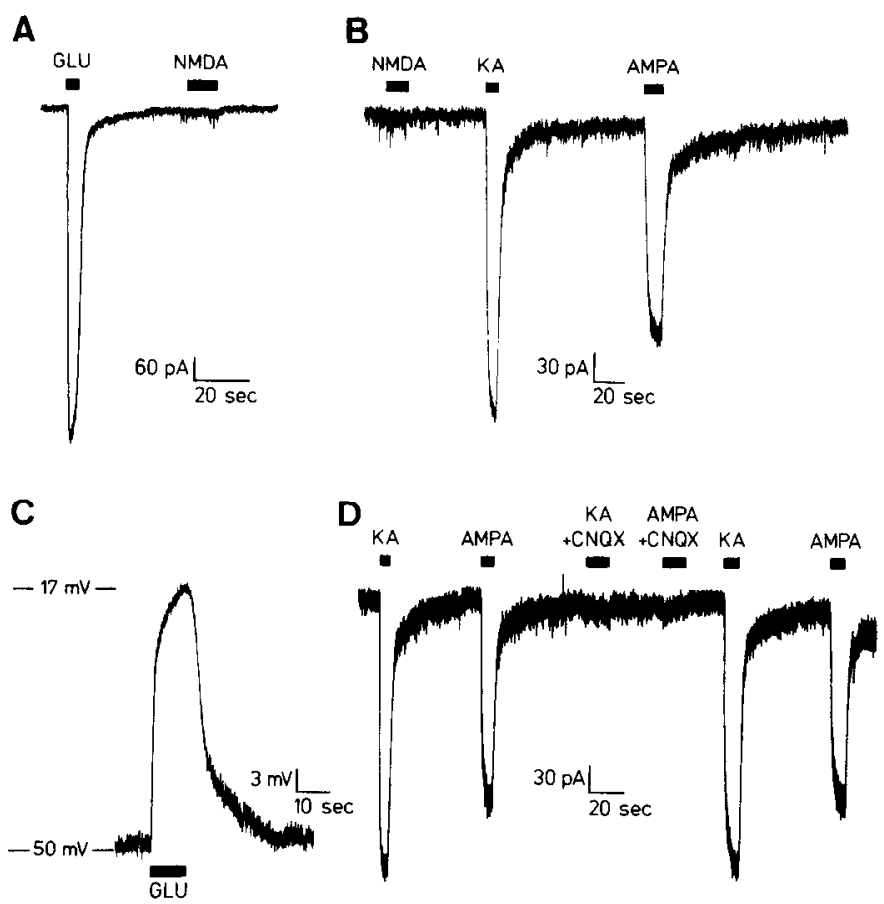

Figure 13. Whole-cell currents induced in AII-amacrine cells by EAA agonists and antagonists (electrode solution I1, bath solution E4). $A$, This AII cell was voltage clamped at $-60 \mathrm{mV}$. Glutamate $(G L U)$ induced a strong inward current, while NMDA had no effect. $B$, Responses of another AII cell to KA and AMPA; no current was induced by NMDA. The bath solution E4 is $\mathrm{Mg}^{2+}$-free and contains glycine $(0.5$ $\mu \mathrm{M}$ ); hence, NMDA currents, if present in AII-amacrine cells, should be recorded in $A$ and $B$. $C$, This AII cell was current clamped at the resting potential of $-50 \mathrm{mV}$. Application of glutamate caused a strong depolarization of the cell (electrode solution I1, bath solution E4). D, Whole-cell currents recorded from an AII cell, voltage clamped at -60 $\mathrm{mV}$ (bath solution E4, electrode solution I1). KA and AMPA were first applied on their own and induced prominent inward currents. Then, KA and AMPA were coapplied with CNQX, which completely blocked the responses. Finally, KA and AMPA were once more applied without CNQX and the currents were measured again.
Figure 12. A, Whole-cell currents recorded from an AII-amacrine cell, which was voltage clamped at $V_{H}=-70 \mathrm{mV}$. Application of glycine $(G L Y)$ alone induced a strong inward current. When the same concentration of glycine was coapplied with strychnine ( $S T R Y)$, this current was strongly suppressed. $B$ When muscimol (MUSC) or glycine were applied, prominent inward currents were elicited. Bicuculline (BIC) when coapplied with muscimol or glycine, only suppressed the miscimol-induced current, while not reducing the glycine-induced current. The glycineinduced current was actually larger during coapplication with bicuculline. This does not mean potentiation of glycine action by bicuculline, but reflects limitations of the application techniques: different barrels of the puffer pipette were not equally effective (bath solution $\mathrm{E} 2$, electrode solution I1).

might be the result of the voltage-dependent $\mathrm{Na}^{+}$and $\mathrm{K}^{+}$channels described in the present study. In conclusion, we interpret the voltage-gated channels found in AII-amacrine cells as "local signal boosters." They may be absent from the cell body and mainly found on dendrites where AII cells make their synaptic connections.

During our search for AII-amacrine cells, we occasionally also recorded and stained other types of amacrine cells. Although these cells were not studied in great detail, it was noticed that certain types of wide-field amacrines show a different spiking pattern when depolarized by current injection. Such cells fired
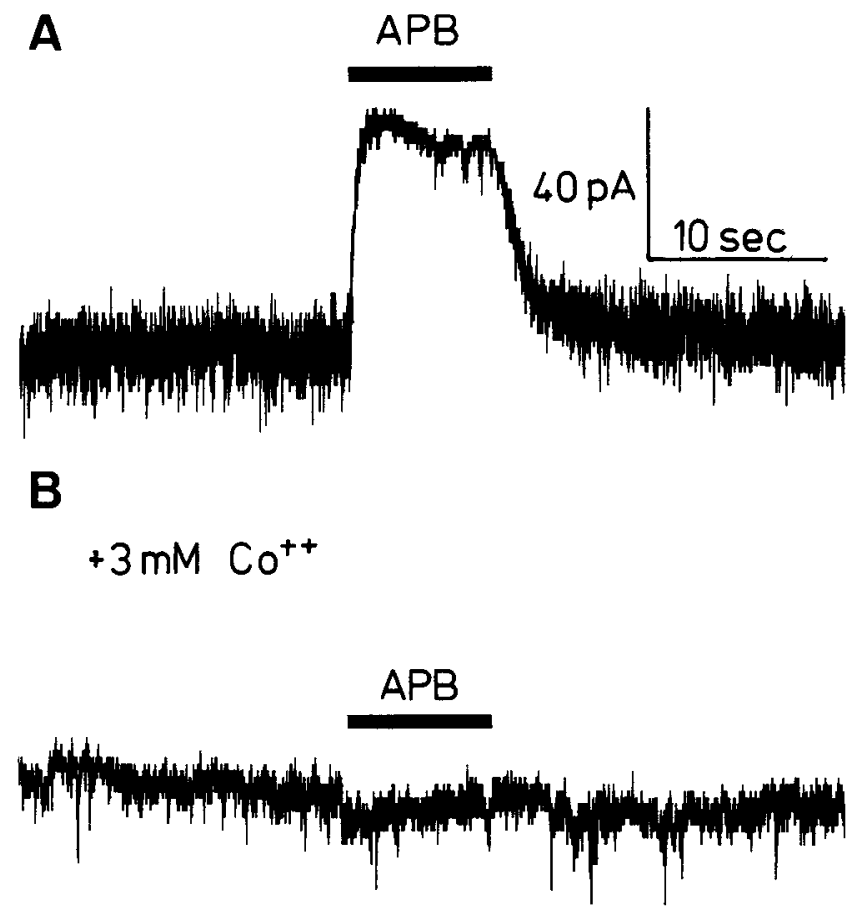

Figure 14. A, APB-activated whole-cell current of an AII-cell, voltage clamped at $V_{H}=-70 \mathrm{mV}$. APB induced an outward current in this cell. $B$, When $3 \mathrm{~mm} \mathrm{Co} \mathrm{Co}^{2+}$ was added to the bathing medium, APB responses were blocked. This suggests APB action was not directly at the AII cell membrane, but indirectly through activation of a presynaptic neuron (intracellular solution E1, extracellular solution I1). 
a single spike at the beginning of the depolarization and were refractory during the sustained depolarization. The voltage-gated $\mathrm{Na}^{+}$channels in these cells were activated at a potential more positive than that of AII-amacrines. In the mudpuppy retina, Barnes and Werblin (1986) and Eliasof et al. (1987) described and analyzed the voltage-gated currents that generate single spike activity in amacrine cells. They showed that steady state inactivation of the voltage-dependent $\mathrm{Na}^{+}$channels blocks these channels at holding potentials more negative than the activation threshold of voltage-dependent $\mathrm{K}^{+}$channels. Therefore, the membrane cannot quickly repolarize and activation of a second spike is not possible. Further experiments have to show whether the same mechanism is responsible for single-spike activity in amacrine cells of the mammalian retina. AlI-amacrines certainly show a sustained firing behavior and, in light of this, it is worth noting that the steady state inactivation of $\mathrm{Na}^{+}$channels and activation of $\mathrm{K}^{+}$channels have overlapping ranges (see Figs. $7,9)$.

\section{Glutamate receptors of AII-amacrine cells}

There is evidence from immunostaining that rod bipolar cells, which provide the major input into AII-amacrine cells, use glutamate as their transmitter (for review, see Massey, 1990). In fish retina the release of glutamate from bipolar cells has been shown more directly (Tachibana and Okada, 1991). The presence of three types of glutamate receptors on AII-amacrine cells has been investigated in the present article. It was found that the KA/AMPA receptor is expressed while NMDA and APB receptors seem not to be expressed by AII-amacrines.

The APB receptor is coupled to a second messenger system (Nawy and Jahr, 1991; Yamashita and Wässle, 1991b; Shiells and Falck, 1992a,b); therefore, possible APB responses were measured with the nystatin method (Horn and Marty, 1988). Since binding of glutamate on the APB receptor closes nonselective cation channels, such synapses are sign reversing. On the contrary, binding of glutamate on the KA/AMPA receptor opens such channels, and the synapses are sign conserving. Our finding that AII cells express the KA/AMPA receptor therefore suggests that the rod bipolar/AII-amacrine synapse is sign conserving. In other words, the depolarization by light of rod bipolar cells results in the release of glutamate, which in turn depolarizes AII-amacrine cells. This is an important result, since a signreversing synapse had been posulated between rod bipolars and AII-amacrines in the cat retina (for review, see Daw et al., 1990).

Despite several efforts, such as recording in low $\mathrm{Mg}^{2+}$, at holding potentials of about $-40 \mathrm{mV}$, or with added glycine, we did not observe NMDA responses in AII-amacrine cells. We had no problems recording NMDA responses in ganglion cells; hence, it is unlikely that we missed NMDA-gated channels for methodological reasons. In a recent study of mudpuppy amacrine cells, Dixon and Copenhagen (1992) found that light responses of sustained amacrine cells do not involve an NMDAtype of receptor; they are blocked by CNQX, suggesting a KA/ AMPA-type of receptor. AII-amacrines also give sustained light responses (Nelson, 1982; Dacheux and Raviola, 1986) and express the KA/AMPA receptors, but not the NMDA type.

The recent isolation of at least five different cDNAs encoding functional subunits of glutamate receptors (Hollmann et al., 1989; Keinänen et al., 1990) might introduce further diversity. In the rat retina all five glutamate receptor genes are expressed, and in the amacrine layer at least four of these receptors seem to be expressed (Hughes et al., 1992; Müller et al., 1992).

\section{$G A B A$, glycine-, and $A C h$ receptors on AII-amacrines}

Reconstructions of AII-amacrines from electron microscopic serial sections have revealed many conventional synapses along their dendritic branches (Sterling et al., 1988; Kolb et al., 1991; Strettoi et al., 1992). Therefore, in addition to the rod bipolar input, other amacrines provide synaptic input into AII-amacrine cells. Using immunocytochemical labeling, both glycinergic and GABAergic synapses were found (Grünert and Wässle, 1991; Kolb et al., 1991). AII-amacrine cells were also labeled with antibodies against glycine receptors (Grünert and Wässle, 1991).

The present study has shown that AII-amacrine cells have GABA- as well as glycine-gated channels in their membrane. Both transmitters open $\mathrm{Cl}^{-}$channels. Although the precise concentration of $\mathrm{Cl}^{-}$in AII-amacrines is not known, the perforatedpatch method applied in the present study allows some conclusions with respect to the $\mathrm{Cl}$ reversal potential. Using nystatin in the patch electrode, GABA or glycine produced hyperpolarizing voltage responses during the first few minutes. Gradually the $\mathrm{Cl}^{-}$in the electrode diffused into the cell and the response became depolarizing. This shows that the $\mathrm{Cl}^{-}$reversal potential of intact AII cells is more negative than the resting potential. Hence, GABAergic or glycinergic synapses hyperpolarize AIIamacrine cells and the amacrines providing this input might cause the lateral inhibition found in AII cells (Nelson, 1982; Dacheux and Raviola, 1986). Since glycinergic amacrines have small dendritic fields (Pourcho and Goebel, 1985) they might provide the antagonistic surround, which is not much wider than the AII receptive-field center (Nelson, 1982). Most GABAergic amacrines have large dendritic fields (Pourcho and Goebel, 1983; Wässle and Boycott, 1991) and they may provide more extended lateral interactions. This remains to be tested in further experiments where the spatial extents of the GABAergic or glycinergic inputs can be measured (Barnes and Werblin, 1987; Lukasiewicz and Werblin, 1990).

AII-amacrines apparently lack ACh receptors. Although cholinergic amacrines are a prominent cell type in all vertebrate retinas (for review, see Masland, 1986) and have been investigated in great detail, we are not aware of any evidence that they might be specifically involved with the rod pathway.

In summary, the mammalian retinal slice preparation can be used to study individual neurons and their pharmacological properties. No precautions were taken in the present study to rescue light responses; actually, we were surprised to find any such responses given the strong bleaching of the retina and the lack of pigment epithelium. We are therefore optimistic that they can be measured routinely when the dissection and microscopy are done under infrared light illumination (Mittman et al., 1990). Such a preparation would be of great potential for further studies of mammalian retinal function.

\section{References}

Ascher P, Bregestovski P, Nowak L (1988) $N$-methyl-D-aspartateactivated channels of mouse central neurones in magnesium-free solutions. J Physiol (I ond) 399:207-226.

Barnes S, Werblin F (1986) Gated currents generate single spike activity in amacrine cells of the tiger salamander retina. Proc Natl Acad Sci USA 83:1509-1512.

Barnes S, Werblin F (1987) Direct excitatory and lateral inhibitory synaptic inputs to amacrine cells in the tiger salamander retina. Brain Res 406:233-237.

Bloomfield SA, Dowling JE (1985) Roles of aspartate and glutamate 
in synaptic transmission in rabbit retina. II. Inner plexiform layer. $\mathbf{J}$ Neurophysiol 53:714-725.

Bolz J, Wässle H, Thier P (1984) Pharmacological modulation of ONand OFF-ganglion cells in the cat retina. Neuroscience 12:875-885.

Bormann J (1990) Patch-clamp studies of glycine-gated chloride channels. In: Glycine neurotransmission (Ottersen OP, Storm-Mathisen J, eds), pp 11-137. New York: Wiley.

Chun MH, Han SH, Chung JW, Wässle H (1993) Electron microscopic analysis of the rod pathway of the rat retina. $J$ Comp Neurol, in press.

Dacheux RF, Raviola E (1986) The rod pathway in the rabbit retina: a depolarizing bipolar and amacrine cell. J Neurosci 6:331-345.

Daw NW, Jensen RW, Brunken WJ (1990) Rod pathways in mammalian retinae. Trends Neurosci 13:110-115.

Dixon DB, Copenhagen DR (1992) Two types of glutamate receptors differentially excite amacrine cells in the tiger salamander retina. J Physiol (Lond) 449:589-606.

Dowling JE (1991) Retinal neuromodulation: the role of dopamine Vis Neurosci 7:87-97.

Edwards FA, Konnerth A, Sakmann B, Takahashi T (1989) A thin slice preparation for patch clamp recordings from neurones of the mammalian central nervous system. Pflugers Arch 414:600-612.

Eliasof S, Barncs S, Werblin FS (1987) The interaction of ionic currents mediating single spike activity in retinal amacrine cells of the tiger salamander. J Neurosci 7:3512-3524.

Famiglietti EV, Kolb H (1975) A bistratified amacrine cell and synaptic circuitry in the inner plexiform layer of the retina. Brain Res 84:293-300

Fenwick EM, Marty A, Neher E (1982) A patch-clamp study of bovine chromaffin cells and of their sensitivity to acetylcholine. J Physiol (Lond) 331:577-597.

Godley BF, Wurtman RJ (1988) Release of endogenous dopamine from the superfused rabbit retina in vitro: effect of light stimulation. Brain Res 452:393-395.

Greferath U, Grünert U, Wässle H (1990) Rod bipolar cells in the mammalian retina show protein kinase C-like immunoreactivity. J Comp Neurol 301:433-442.

Grünert U, Wässle H (1991) Localization of glycine receptors in the cat and monkey retina. Invest Ophthalmol Vis Sci 32:ARVO Abstract 2553.

Hamill OP, Marty A, Neher E, Sakmann B, Sigworth F (1981) Improved patch-clamp techniques for high resolution current recordings from cells and cell free membrane patches. Pflugers Arch 391:85100.

Hampson ECGM, Vaney DI, Weiler R (1992) Dopaminergic modulation of gap junction permeability between amacrine cells in mammalian retina. J Neurosci 12:4911-4922.

Hille B (1992) Ionic channels of excitable membranes. Sunderland, MA: Sinauer.

Hollmann M, O'Shea-Greenfield A, Rogers SW, Heinemann S (1989) Cloning by functional expression of a member of glutamate receptor family. Nature 342:643-648.

Horikawa K, Armstrong WE (1988) A versatile means of intracellular labeling: injection of biocytin and its detection with avidin conjugates. J Neurosci Methods 25:1-11.

Horn R, Marty A (1988) Muscarinic activation of ionic currents measured by a new whole-cell recording method. J Gen Physiol 92:145159.

Hughes TE, Hermans-Borgmeyer I, Heinemann S (1992) Differential expression of glutamate receptor genes (GluR 1-5) in the rat retina. Vis Neurosci 8:49-55.

Ishhida AT (1992) The physiology of $\mathrm{GABA}_{\mathrm{A}}$ receptors in retinal neurons. In: Progress in brain research (Mize RR, Marc RE, Sillito AM, eds), pp 29-45. Amsterdam: North Holland-Elsevier.

Kaneda M, Kaneko A (1991) Voltage-gated sodium currents in isolated retinal ganglion cells of the cat: relation between the inactivation kinetics and the cell type. Neurosci Res 11:261-275.

Kaneko A, Pinto LH, Tachibana M (1989) Transient calcium current of retinal bipolar cells of the mouse. J Physiol (Lond) 410:613-629.

Kaneko A, de Villa P, Kurahashi T (1992) L-Glutamate-induced responses in isolated cat bipolar cells the subtype of which was identified by PKC-like immunoreactivity. Invest Ophthalmol Vis Sci 33:ARVO Ahstract 293.

Karschin A, Wässle H (1990) Voltage- and transmitter-gated currents in isolated rod bipolar cells of the rat retina. J Neurophysiol 63:860876.

Keinänen K, Wisden W, Sommer B, Werner P, Herb A, Verdoorn TA,
Sakmann B, Seeburg PH (1990) A family of AMPA-selective glutamate receptors. Science 249:556-560.

Kenan-Vaknin G, Katz H, Malach R (1992) Golgi-like staining of visual cortex cells obtained by extracellular biocytin application in vitro. Brain Res 571:338-341.

Klumpp DJ, Farber DB, Bowes C, Song EJ, Pinto LH (1991) The potassium channel MBK1 (Kvl.1) is expressed in the mouse retina. Cell Mol Neurobiol 11:611-622.

Kolb $H$ (1979) The inner plexiform layer in the retina of the cat: electron microscopic observations. J Neurocytol 8:295-329.

Kolb H, Famiglietti EV (1974) Rod and cone pathways in the inner plexiform layer of the cat retina. Science 186:47-49.

Kolb H, Nelson R (1983) Rod pathways in the retina of the cat. Vision Kes 23:301-312

Kolb H, Cuenca N, Wang HH, Dekorver L (1990) The synaptic organization of the dopaminergic amacrine cell in the cat retina. J Neurocytol 19:343-366.

Kolb H, Cuenca N, Dekorver L (1991) Postembedding immunocytochemistry for GABA and glycine reveals the synaptic relationships of the dopaminergic amacrine cell of the cat retina. J Comp Neurol 310:267-284.

Konnerth $\Lambda$, Obaid $\Lambda \mathbf{L}$, Salzberg BM (1987) Optical recording of electrical activity from parallel fibres and other cell types in skate cerebellar slices in vitro. J Physiol (Lond) 393:681-702.

Lipton S, Tauck DL (1987) Voltage-dependent conductances of solitary ganglion cells dissociated from the rat retina. J Physiol (Lond) 385:361-391.

Lukasiewicz PD, Werblin FS (1990) The spatial distribution of excitatory and inhibitory inputs to ganglion cell dendrites in the tiger salamander retina. J Neurosci 10:210-221.

Masland RH (1986) The functional architecture of the retina. Sci Am 254:102-111.

Massey SC (1990) Cell types using glutamate as a neurotransmitter in the vertebrate retina. In: Progress in retinal research, Vol 9 (Osborne NN, Chader GJ, eds), pp 399-425. Oxford: Pergamon.

Masscy SC, Miller RG (1988) Glutamate receptors of ganglion cells in the rabbit retina: evidence for glutamate as a bipolar cell transmitter. J Physiol (Lond) 405:635-655.

Massey SC, Redburn DA (1987) Transmitter circuits in the vertebrate retina. Prog Neurobiol 28:55-96.

Massey SC, Redburn DA, Crawford MLJ (1983) The effects of 2-amino4-phosphonobutyric acid (APB) on the ERG and ganglion cell discharge of rabbit retina. Vision Res 23:1607-1613.

Mayer ML, Westbrook GL (1987) Permeation and block of $N$-methylD-aspartic acid receptor channels by divalent cations in mouse cultured central neurones. J Physiol (Lond) 394:501-527.

Miller RF, Dacheux R (1976) Dendritic and somatic spikes in mudpuppy amacrine cells: identification and TTX sensitivity. Brain Res 104:157-162.

Mills SI, Masscy SC (1991) Labcling and distribution of AII amacrine cells in the rabbit retina. J Comp Neurol 304:491-501.

Mittman S, Taylor R, Copenhagen D (1990) Concomitant activation of two types of glutamate receptor mediates excitation of salamander retinal ganglion cells. J Physiol (Lond) 428:175-197.

Müller F, Wässle $H$, Voigt T (1988) Pharmacological modulation of the rod pathway in the cat retina. J Neurophysiol 59:1657-1672.

Müller F, Greferath U, Wässle H, Wisden W, Seeburg P (1992) Glutamate receptor expression in the rat retina. Neurosci Lett 138:179182.

Nawy S, Jahr CE (1991) cGMP-gated conductance in retinal bipolar cells is suppressed by the photoreceptor transmitter. Neuron 7:677683 .

Negishi K, Kato S, Teranishi T (1988) Dopamine cells and rod bipolar cells contain protein kinase C-like immunorcactivity in some vertebrate retinas. Neurosci Lett 94:247-252.

Nelson R (1982) AII amacrine cells quicken time course of rod signals in the cat retina. J Neurophysiol 47:928-947.

Nelson R, Kolb H (1983) Synaptic patterns and response properties of bipolar and ganglion cells in the cat retina. Vision Res 23:11831195.

Parkinson D, Rando RR (1983) Effect of light on dopamine turnover and metabolism in rabbit retina. Invest Ophthalmol Vis Sci 24:384 388

Patlak J (1991) Molecular kinetics of voltage-dependent $\mathrm{Na}^{+}$channels. Physiol Rev 71:1047-1080.

Perry VH, Walker M (1980) Amacrine cells, displaced amacrine cells 
and interplexiform cells in the retina of the rat. Proc $\mathrm{R}$ Soc Lond [Biol] 208:415-431.

Pourcho RG (1982) Dopaminergic amacrine cells in the rat retina. Brain Res 252:101-109.

Pourcho RG, Goebel DJ (1983) Neuronal subpopulations in cat retina which accumulate the GABA agonist, $\left({ }^{3} \mathrm{H}\right)$ muscimol: a combined Golgi autoradiographic study. J Comp Neurol 219:25-35.

Pourcho RG, Goebel DJ (1985) A combined Golgi and autoradiographic study of $\left({ }^{3} \mathrm{H}\right)$-glycine-accumulating amacrine cells in the cat retina. J Comp Neurol 233:473-480.

Pourcho RG, Goebel DJ (1987) Visualization of endogeneous glycine in cat retina: an immunocytochemical study with Fab fragments. $\mathbf{J}$ Neurosci 7:1189-1197.

Röhrenbeck J, Wässle H, Heizmann CW (1987) Immunocytochemical labelling of horizontal cells in mammalian retina using antibodies against calcium-binding proteins. Neurosci Lett 77:255-260.

Röhrenbeck J, Wässle H, Boycott BB (1989) Horizontal cells in the monkey retina: immunocytochemical staining with antibodies against calcium binding proteins. Eur J Neurosci 1:407-420.

Salkoff L, Baker K, Butler A, Covarrubias M, Pak WD, Wei A (1992) An essential 'set' of $\mathrm{K}^{+}$channels conserved in flies, mice and humans. Trends Neurosci 15:161-166.

Shiells RA, Falk G (1992a) The glutamate-receptor linked cGMP cascade of retinal on-bipolar cells is pertussis and cholera toxinsensitive. Proc R Soc Lond [Biol] 247:17-20.

Shiells RA, Falk G (1992b) Properties of the cGMP-activated channel of retinal on-bipolar cells. Proc R Soc Lond [Biol] 247:21-25.

Slaughter MM, Miller RF (1981) 2-Amino-4-phosphonobutyric acid: a new pharmacological tool for retina research. Science 21 1:182-185.

Sterling P (1983) Microcircuitry of the cat retina. Annu Rev Neurosci 6:149-185.

Sterling P, Freed MA, Smith RG (1988) Architecture of rod and cone circuits to the ON-beta ganglion cells. J Neurosci 8:623-642.

Stern P, Edwards FA, Sakmann B (1992) Fast and slow components of unitary EPSCs on stellate cells elicited by focal stimulation in slices of rat visual cortex. J Physiol (Lond) 449:247-278.

Stewart WW (1978) Functional connections between cells as revealed by dye-coupling with a highly fluorescent naphthalimide tracer. Cell 14:741-759.

Strettoi E, Dacheux RF, Raviola E (1990) Synaptic connections of rod bipolar cells in the inner plexiform layer of the rabbit retina. J Comp Neurol 295:449-466.

Strettoi E, Raviola E, Dacheux RF (1992) Synaptic connections of the narrow-ficld, bistratificd rod amacrinc cell (AII) in the rabbit retina. J Comp Neurol 325:152-168.

Stuart G, Sakmann B (1992) Voltage activated channels in neocortical pyramidal cell dendrites. Eur J Neurosci [Suppl] 5:ENA Abstract 2071.

Stühmer W, Conti F, Suzuki H, Wang X, Noda M, Yahagi N, Kubo
H, Numa S (1989) Structural parts involved in activation and inactivation of the sodium channel. Nature 339:597-603.

Tachibana M, Okada T (1991) Release of endogenous excitatory amino acids from ON-type bipolar cells isolated from the goldfish retina. J Neurosci 11:2199-2208.

Vaney DI (1985) The morphology and topographic distribution of AII amacrine cells in the cat retina. Proc $R$ Soc Lond [Biol] 224:475-488.

Vaney DI (1990) The mosaic of amacrine cells in the mammalian retina. In: Progress in retinal research, Vol 9 (Osborne NN, Chader GJ, eds), pp 49-100. Oxford: Pergamon.

Vaney DI (1991) Many diverse types of retinal neurons show tracer coupling when injected with biocytin or neurobiotin. Neurosci Lett 125:187-190.

Vaney DI, Gynther IC, Young HM (1991) Rod-signal interneurons in the rabbit retina: 2 . AII amacrine cells. J Comp Neurol 310:154 169.

Voigt T (1986) Cholinergic amacrine cells in the rat retina. J Comp Neurol 248:19-35.

Voigt T, Wässle H (1987) Dopaminergic innervation of AII amacrine cells in mammalian retina. $J$ Neurosci 7:4115-4128.

Wässle H, Boycott BB (1991) Functional architecture of the mammalian retina. Physiol Rev 71:447-480.

Wässle H, Grünert U, Röhrenbeck J (1993) Immunocytochemical staining of AII amacrine cells in the rat retina with antibodies against parvalbumin. J Comp Neurol, in press.

Watkins JC, Krogsgaard-Larsen P, Honoré T (1990) Structure-activity relationships in the development of excitatory amino acid receptor agonists and competitive antagonists. Trends Pharmacol Sci 11:2533.

Werblin FS (1978) Transmission along and between rods in the tiger salamander retina. J Physiol (Lond) 280:449-470.

Werblin FS, Maguire PD, Lukasiewicz PD, Eliasof SR, Wu S (1988) Neural interactions mediating the detection of motion in the retina of the tiger salamander. Vis Neurosci 1:317-329.

Witkovsky P, Dearry A (1991) Functional roles of dopamine in the vertebrate retina. In: Progress in retinal research, Vol 10 (Osborne NN, Chader GJ, eds), pp 247-292. Oxford: Pergamon.

Wu SMS (1987) Synaptic connections between neurons in living slices of the larval tiger salamander retina. J Neurosci Methods 20:139149.

Yamashita M, Wässle H (1991a) The reversal potential of GABAinduced currents in rod bipolar cells of the rat retina. Vis Neurosci 6:399-401.

Yamashita M, Wässle H (1991b) Responses of rod bipolar cells isolated from the rat retina to the glutamate agonist 2-amino-4-phosphonobutyric acid (APB). J Neurosci 11:2372-2382.

Yeh HH, Lee MB, Cheun JE (1990) Properties of GABA-activated whole-cell currents in bipolar cells of the rat retina. Vis Neurosci $4: 349-357$. 